PRESIDEN

REPUBLIK INDONESIA

UNDANG-UNDANG REPUBLIK INDONESIA

NOMOR 23 TAHUN 2019

TENTANG

PENGELOLAAN SUMBER DAYA NASIONAL

UNTUK PERTAHANAN NEGARA

DENGAN RAHMAT TUHAN YANG MAHA ESA

PRESIDEN REPUBLIK INDONESIA,

Menimbang : a. bahwa setiap warga negara berhak dan wajib ikut serta dalam usaha pertahanan dan keamanan negara sebagaimana diamanatkan dalam Undang-Undang Dasar Negara Republik Indonesia Tahun 1945;

b. bahwa sistem pertahanan negara bersifat semesta yang melibatkan seluruh sumber daya nasional yang dipersiapkan secara dini oleh Pemerintah dan diselenggarakan secara total, terpadu, terarah, dan berkelanjutan untuk menegakkan kedaulatan negara, menjaga keutuhan wilayah, dan keselamatan segenap bangsa dari segala bentuk ancaman;

c. bahwa Undang-Undang Nomor 3 Tahun 2002 tentang Pertahanan Negara mengamanatkan mengenai usaha bela negara, komponen cadangan, dan komponen pendukung diatur dengan Undang-Undang;

d. bahwa berdasarkan pertimbangan sebagaimana dimaksud dalam huruf a, huruf $b$, dan huruf $c$, perlu membentuk Undang-Undang tentang Pengelolaan Sumber Daya Nasional untuk Pertahanan Negara;

Mengingat: . . . 


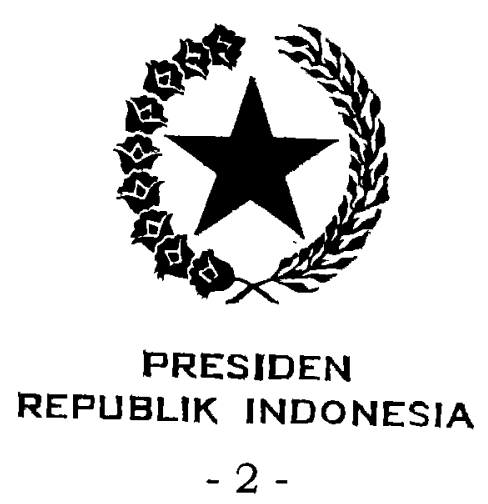

Mengingat : 1. Pasal 5 ayat (1), Pasal 20, Pasal 27 ayat (3), Pasal 30 ayat (1) dan ayat (2) Undang-Undang Dasar Negara Republik Indonesia Tahun 1945;

2. Undang-Undang Nomor 3 Tahun 2002 tentang Pertahanan Negara (Lembaran Negara Republik Indonesia Tahun 2002 Nomor 3, Tambahan Lembaran Negara Nomor 4169);

Dengan Persetujuan Bersama

DEWAN PERWAKILAN RAKYAT REPUBLIK INDONESIA

dan

PRESIDEN REPUBLIK INDONESIA

MEMUTUSKAN:

Menetapkan : UNDANG-UNDANG TENTANG PENGELOLAAN SUMBER DAYA NASIONAL UNTUK PERTAHANAN NEGARA.

BAB I

KETENTUAN UMUM

Pasal 1

Dalam Undang-Undang ini yang dimaksud dengan:

1. Pertahanan Negara adalah segala usaha untuk mempertahankan kedaulatan negara, keutuhan wilayah Negara Kesatuan Republik Indonesia, dan keselamatan segenap bangsa dari ancaman serta gangguan terhadap keutuhan bangsa dan negara.

2. Ancaman adalah setiap usaha dan kegiatan, baik dari dalam negeri maupun luar negeri yang bertentangan dengan Pancasila dan mengancam atau membahayakan kedaulatan negara, keutuhan wilayah Negara Kesatuan Republik Indonesia, dan keselamatan segenap bangsa.

3. Sumber Daya Nasional adalah sumber daya manusia, sumber daya alam, dan sumber daya buatan.

4. Sumber ... 


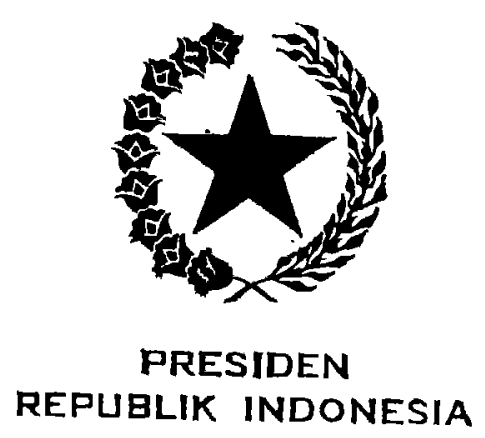

$-3-$

4. Sumber Daya Manusia adalah warga negara yang memberikan daya dan usahanya untuk kepentingan bangsa dan negara.

5. Sumber Daya Alam adalah potensi yang terkandung dalam bumi, air, dan udara yang dalam wujud asalnya dapat didayagunakan untuk kepentingan Pertahanan Negara.

6. Sumber Daya Buatan adalah Sumber Daya Alam yang telah ditingkatkan daya gunanya untuk kepentingan Pertahanan Negara.

7. Sarana dan Prasarana Nasional adalah hasil budi daya manusia yang dapat digunakan sebagai alat penunjang untuk kepentingan Pertahanan Negara dalam rangka mendukung kepentingan nasional.

8. Komponen Utama adalah Tentara Nasional Indonesia yang siap digunakan untuk melaksanakan tugas pertahanan.

9. Komponen Cadangan adalah Sumber Daya Nasional yang telah disiapkan untuk dikerahkan melalui mobilisasi guna memperbesar dan memperkuat kekuatan dan kemampuan Komponen Utama.

10. Komponen Pendukung adalah Sumber Daya Nasional yang dapat digunakan untuk meningkatkan kekuatan dan kemampuan Komponen Utama dan Komponen Cadangan.

11. Bela Negara adalah tekad, sikap, dan perilaku serta tindakan warga negara, baik secara perseorangan maupun kolektif dalam menjaga kedaulatan negara, keutuhan wilayah, dan keselamatan bangsa dan negara yang dijiwai oleh kecintaannya kepada Negara Kesatuan Republik Indonesia yang berdasarkan Pancasila dan Undang-Undang Dasar Negara Republik Indonesia Tahun 1945 dalam menjamin kelangsungan hidup bangsa Indonesia dan Negara dari berbagai Ancaman. 


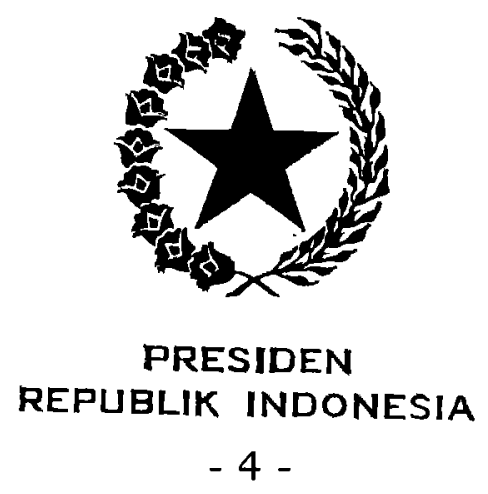

12. Pembinaan Kesadaran Bela Negara adalah segala usaha, tindakan, dan kegiatan yang dilaksanakan dalam rangka memberikan pengetahuan, pendidikan, dan/atau pelatihan kepada warga negara guna menumbuhkembangkan sikap dan perilaku serta menanamkan nilai dasar Bela Negara.

13. Mobilisasi adalah tindakan pengerahan dan penggunaan secara serentak Sumber Daya Nasional serta Sarana dan Prasarana Nasional yang telah dipersiapkan dan dibina sebagai komponen kekuatan Pertahanan Negara untuk digunakan secara tepat, terpadu, dan terarah bagi penanggulangan setiap Ancaman, baik dari luar negeri maupun dari dalam negeri yang membahayakan persatuan dan kesatuan bangsa serta kelangsungan hidup bangsa dan Negara Kesatuan Republik Indonesia.

14. Demobilisasi adalah tindakan penghentian pengerahan dan penggunaan Sumber Daya Nasional serta Sarana dan Prasarana Nasional setelah melaksanakan tugas Mobilisasi.

15. Warga Negara adalah warga negara Republik Indonesia.

16. Panglima Tentara Nasional Indonesia adalah perwira tinggi militer yang memimpin Tentara Nasional Indonesia.

17. Menteri adalah menteri yang menyelenggarakan urusan pemerintahan di bidang pertahanan.

18. Pemerintah Pusat yang selanjutnya disebut Pemerintah adalah Presiden Republik Indonesia yang memegang kekuasaan pemerintahan Negara Republik Indonesia yang dibantu oleh Wakil Presiden dan menteri sebagaimana dimaksud dalam Undang-Undang Dasar Negara Republik Indonesia Tahun 1945.

BAB II . . 


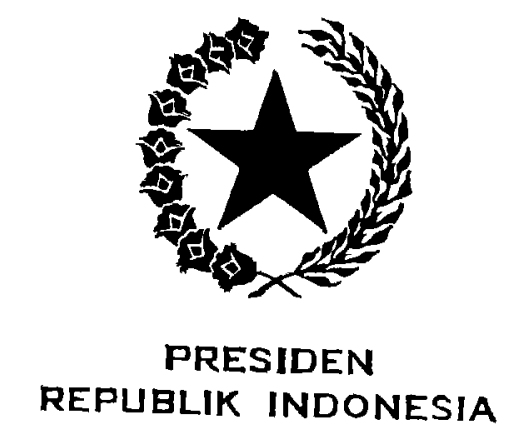

-5 -

BAB II

ASAS, TUJUAN, DAN RUANG LINGKUP

\section{Bagian Kesatu \\ Asas}

\section{Pasal 2}

Penyelenggaraan pengelolaan Sumber Daya Nasional untuk Pertahanan Negara berdasarkan asas:
a. tujuan;
b. kesemestaan;
c. kejuangan;
d. kebersamaan dan gotong royong;
e. manfaat;
f. legalitas;
g. selektivitas;
h. efektivitas;
i. efisiensi; dan
j. proporsionalitas.

\section{Bagian Kedua \\ Tujuan}

\section{Pasal 3}

Pengelolaan Sumber Daya Nasional untuk Pertahanan Negara bertujuan untuk mentransformasikan Sumber Daya Manusia, Sumber Daya Alam, dan Sumber Daya Buatan, serta Sarana dan Prasarana Nasional menjadi kekuatan Pertahanan Negara yang siap digunakan untuk kepentingan Pertahanan Negara.

\section{Bagian Ketiga \\ Ruang Lingkup}

Pasal 4

(1) Pengelolaan Sumber Daya Nasional untuk Pertahanan Negara dipersiapkan secara dini untuk menghadapi Ancaman.

(2) Ancaman ... 


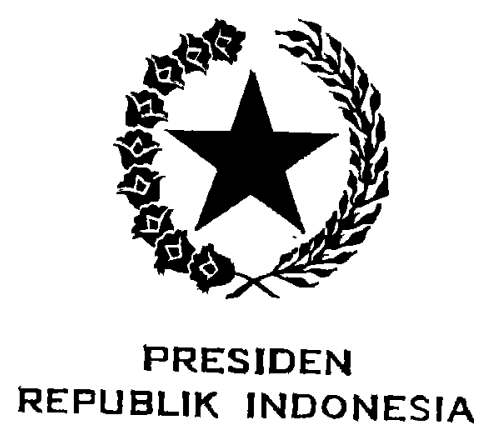

$-6-$

(2) Ancaman sebagaimana dimaksud pada ayat (1) terdiri atas:

a. Ancaman militer;

b. Ancaman nonmiliter; dan/atau

c. Ancaman hibrida.

(3) Ancaman sebagaimana dimaksud pada ayat (2) dapat berwujud agresi, terorisme, komunisme, separatisme, pemberontakan bersenjata, bencana alam, kerusakan lingkungan, pelanggaran wilayah perbatasan, perompakan dan pencurian sumber daya alam, wabah penyakit, peredaran dan penyalahgunaan narkoba, serangan siber, serangan nuklir, serangan biologi, serangan kimia, atau wujud Ancaman yang membahayakan kedaulatan negara, keutuhan wilayah Negara Kesatuan Republik Indonesia, dan keselamatan segenap bangsa.

\section{Pasal 5}

(1) Pengelolaan Sumber Daya Nasional untuk Pertahanan Negara dilaksanakan melalui usaha:
a. Bela Negara;
b. penataan Komponen Pendukung;
c. pembentukan Komponen Cadangan;
d. penguatan Komponen Utama; dan
e. Mobilisasi dan Demobilisasi.

(2) Ketentuan mengenai pengelolaan Sumber Daya Nasional dalam usaha penguatan Komponen Utama sebagaimana dimaksud pada ayat (1) huruf d dilaksanakan sesuai dengan ketentuan peraturan perundang-undangan.

\section{BAB III \\ BELA NEGARA \\ Bagian Kesatu \\ Umum}

\section{Pasal 6}

(1) Setiap Warga Negara berhak dan wajib ikut serta dalam usaha Bela Negara yang diwujudkan dalam penyelenggaraan Pertahanan Negara.

(2) Keikutsertaan . . . 


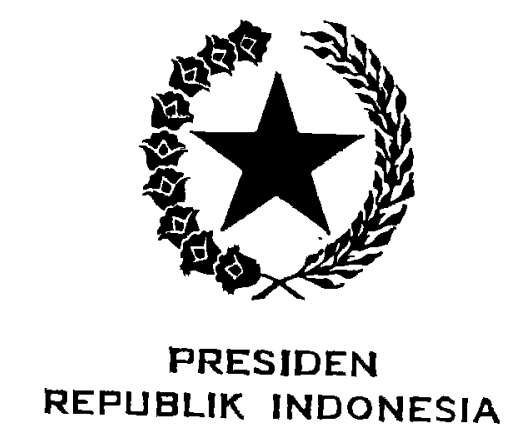

$-7-$

(2) Keikutsertaan Warga Negara dalam usaha Bela Negara sebagaimana dimaksud pada ayat (1) diselenggarakan melalui:

a. pendidikan kewarganegaraan;

b. pelatihan dasar kemiliteran secara wajib;

c. pengabdian sebagai prajurit Tentara Nasional Indonesia secara sukarela atau secara wajib; dan

d. pengabdian sesuai dengan profesi.

(3) Hak Warga Negara dalam usaha Bela Negara sebagaimana dimaksud pada ayat (1) berupa:

a. mendapatkan pendidikan kewarganegaraan yang dilaksanakan melalui Pembinaan Kesadaran Bela Negara;

b. mendaftar sebagai calon anggota Tentara Nasional Indonesia; dan

c. mendaftar sebagai calon anggota Komponen Cadangan.

(4) Kewajiban Warga Negara dalam usaha Bela Negara sebagaimana dimaksud pada ayat (1) meliputi:

a. kewajiban yang diberlakukan kepada Warga Negara yang menjadi prajurit Tentara Nasional Indonesia sebagai alat Pertahanan Negara; dan

b. kewajiban yang diberlakukan kepada Warga Negara sebagai anggota Komponen Cadangan yang diMobilisasi dalam menghadapi Ancaman militer dan Ancaman hibrida.

(5) Pelatihan dasar kemiliteran secara wajib sebagaimana dimaksud pada ayat (2) huruf b diberlakukan kepada calon Komponen Cadangan yang telah memenuhi persyaratan.

\author{
Bagian Kedua \\ Pendidikan Kewarganegaraan
}

Pasal 7

(1) Pendidikan kewarganegaraan sebagaimana dimaksud dalam Pasal 6 ayat (2) huruf a dilaksanakan melalui Pembinaan Kesadaran Bela Negara dengan menanamkan nilai dasar Bela Negara.

(2) Pembinaan ... 


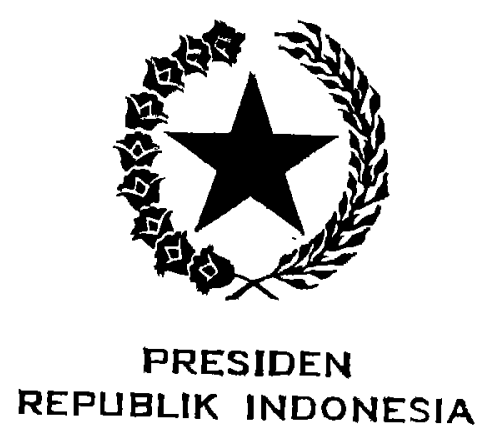

$-8-$

(2) Pembinaan Kesadaran Bela Negara sebagaimana dimaksud pada ayat (1) diselenggarakan di lingkup:
a. pendidikan;
b. masyarakat; dan
c. pekerjaan.

(3) Nilai dasar Bela Negara sebagaimana dimaksud pada ayat
(1) meliputi:
a. cinta tanah air;
b. sadar berbangsa dan bernegara;
c. setia pada Pancasila sebagai ideologi negara;
d. rela berkorban untuk bangsa dan negara; dan
e. kemampuan awal Bela Negara.

\section{Pasal 8}

(1) Pembinaan Kesadaran Bela Negara lingkup pendidikan sebagaimana dimaksud dalam Pasal 7 ayat (2) huruf a dilaksanakan melalui sistem pendidikan nasional.

(2) Pembinaan Kesadaran Bela Negara sebagaimana dimaksud pada ayat (1) diselenggarakan pada setiap jalur, jenjang, dan jenis pendidikan.

(3) Pembinaan Kesadaran Bela Negara melalui sistem pendidikan nasional sebagaimana dimaksud pada ayat (1) dilaksanakan oleh Menteri bekerja sama dengan menteri yang menyelenggarakan urusan pemerintahan di bidang pendidikan.

\section{Pasal 9}

Pembinaan Kesadaran Bela Negara lingkup masyarakat sebagaimana dimaksud dalam Pasal 7 ayat (2) huruf b ditujukan bagi Warga Negara yang meliputi:
a. tokoh agama;
b. tokoh masyarakat;
c. tokoh adat;
d. kader organisasi masyarakat;
e. kader organisasi komunitas;
f. kader organisasi profesi;
g. kader partai politik; dan
h. kelompok masyarakat lainnya.

Pasal $10 \ldots$ 


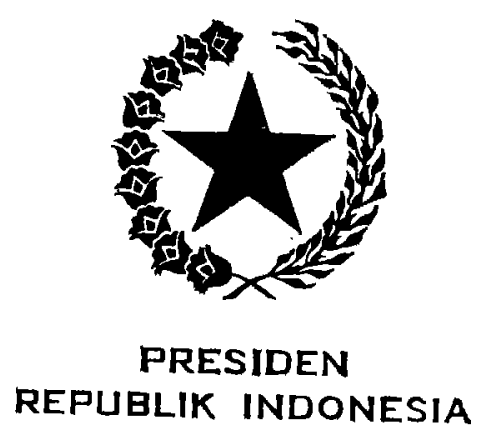

$-9-$

Pasal 10

Pembinaan Kesadaran Bela Negara lingkup pekerjaan sebagaimana dimaksud dalam Pasal 7 ayat (2) huruf $c$ ditujukan bagi Warga Negara yang bekerja pada:

a. lembaga negara;

b. kementerian/lembaga pemerintah nonkementerian dan pemerintah daerah;

c. Tentara Nasional Indonesia;

d. Kepolisian Negara Republik Indonesia;

e. badan usaha milik negara/badan usaha milik daerah;

f. badan usaha swasta; dan

g. badan lain sesuai dengan ketentuan peraturan perundangundangan.

\section{Pasal 11}

(1) Pemerintah menyelenggarakan Pembinaan Kesadaran Bela Negara sebagaimana dimaksud dalam Pasal 8, Pasal 9, dan Pasal 10.

(2) Dalam penyelenggaraan Pembinaan Kesadaran Bela Negara sebagaimana dimaksud pada ayat (1), Pemerintah dapat bekerja sama dengan pemerintah daerah dan pihak lainnya sesuai dengan ketentuan peraturan perundangundangan.

(3) Ketentuan lebih lanjut mengenai penyelenggaraan Pembinaan Kesadaran Bela Negara sebagaimana dimaksud pada ayat (1) dan ayat (2) diatur dengan Peraturan Pemerintah.

\section{Pasal 12}

(1) Dalam penyelenggaraan Pembinaan Kesadaran Bela Negara sebagaimana dimaksud dalam Pasal 11, Pemerintah menetapkan kebijakan Pembinaan Kesadaran Bela Negara.

(2) Kebijakan ... 


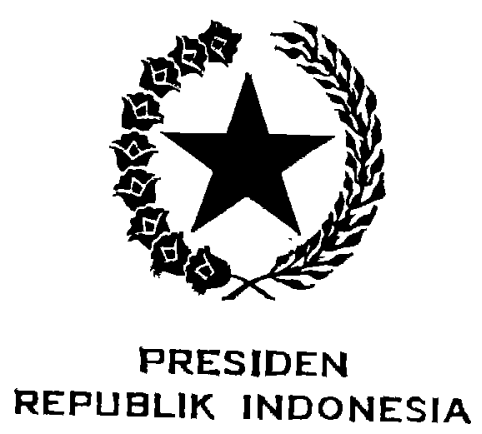

-10 -

(2) Kebijakan sebagaimana dimaksud pada ayat (1) paling sedikit terdiri atas:
a. perencanaan;
b. program kegiatan;
c. pelaksanaan;
d. pengawasan; dan
e. evaluasi.

(3) Ketentuan lebih lanjut mengenai kebijakan Pembinaan Kesadaran Bela Negara sebagaimana dimaksud pada ayat (1) dan ayat (2) diatur dengan Peraturan Presiden.

\section{Bagian Ketiga \\ Pelatihan Dasar Kemiliteran secara Wajib}

Pasal 13

(1) Pelatihan dasar kemiliteran secara wajib sebagaimana dimaksud dalam Pasal 6 ayat (2) huruf b hanya diberlakukan bagi Warga Negara sebagai calon Komponen Cadangan yang telah memenuhi persyaratan.

(2) Menteri bertanggung jawab atas penyelenggaraan pelatihan dasar kemiliteran secara wajib untuk pembentukan calon Komponen Cadangan.

(3) Pelatihan dasar kemiliteran secara wajib sebagaimana dimaksud pada ayat (1) dilaksanakan sesuai dengan ketentuan mengenai pembentukan Komponen Cadangan yang diatur dalam Undang-Undang ini.

\section{Bagian Keempat}

Pengabdian sebagai Prajurit Tentara Nasional Indonesia secara Sukarela atau secara Wajib

\section{Pasal 14}

Pengabdian sebagai prajurit Tentara Nasional Indonesia secara sukarela atau secara wajib sebagaimana dimaksud dalam Pasal 6 ayat (2) huruf c dilaksanakan sesuai dengan ketentuan peraturan perundang-undangan. 


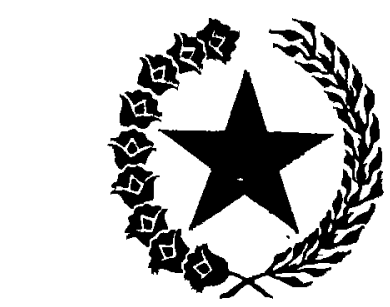

PRESIDEN

REPUBLIK INDONESIA

-11 -

Bagian Kelima

Pengabdian sesuai dengan Profesi

Pasal 15

(1) Setiap Warga Negara melaksanakan pengabdian sesuai dengan profesinya sebagaimana dimaksud dalam Pasal 6 ayat (2) huruf d untuk kepentingan Pertahanan Negara.

(2) Pengabdian sesuai dengan profesi sebagaimana dimaksud pada ayat (1) disiapkan secara dini untuk menghadapi Ancaman militer, Ancaman nonmiliter, dan Ancaman hibrida.

(3) Pengabdian sesuai dengan profesi untuk menghadapi Ancaman militer dan Ancaman hibrida sebagaimana dimaksud pada ayat (2) dilakukan melalui keanggotaan Komponen Cadangan dan/atau Komponen Pendukung.

(4) Pengabdian sesuai dengan profesi untuk menghadapi Ancaman nonmiliter sebagaimana dimaksud pada ayat (2) dikoordinasikan oleh kementerian/lembaga pemerintah nonkementerian sesuai dengan bidang profesi yang berkaitan dengan tugas dan fungsi kementerian/lembaga pemerintah nonkementerian.

\section{Pasal 16}

(1) Pemerintah wajib memberikan pembinaan kepada Warga Negara dalam melaksanakan pengabdian sesuai dengan profesi sebagaimana dimaksud dalam Pasal 15 ayat (4).

(2) Dalam melaksanakan pembinaan sebagaimana dimaksud pada ayat (1), Pemerintah dapat bekerja sama dengan organisasi profesi.

(3) Ketentuan lebih lanjut mengenai pembinaan dan kerja sama dalam pelaksanaan pengabdian sesuai dengan profesi sebagaimana dimaksud pada ayat (1) dan ayat (2) diatur dengan Peraturan Pemerintah. 


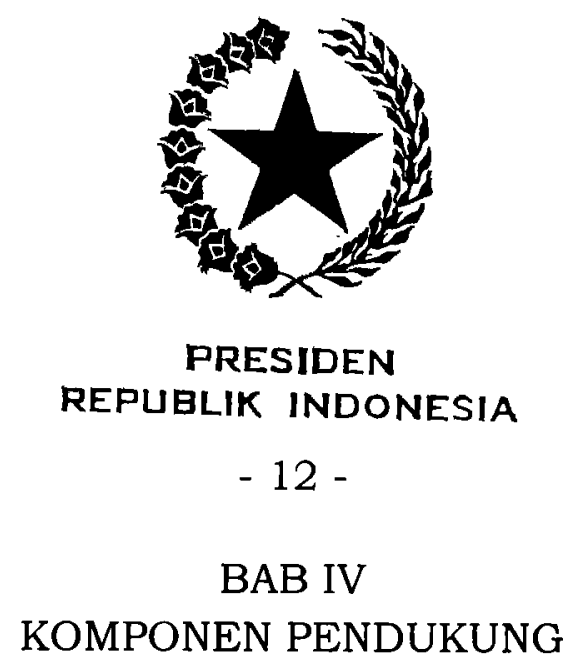

\author{
Bagian Kesatu \\ Umum
}

Pasal 17

(1) Komponen Pendukung terdiri atas:
a. Warga Negara;
b. Sumber Daya Alam;
c. Sumber Daya Buatan; dan
d. Sarana dan Prasarana Nasional.

(2) Komponen Pendukung sebagaimana dimaksud pada ayat (1) merupakan salah satu wadah keikutsertaan Warga Negara secara sukarela dan pemanfaatan Sumber Daya Alam, Sumber Daya Buatan, serta Sarana dan Prasarana Nasional dalam usaha penyelenggaraan Pertahanan Negara.

\title{
Pasal 18
}

Komponen Pendukung sebagaimana dimaksud dalam Pasal 17 ayat (1) dapat digunakan secara langsung atau tidak langsung untuk menghadapi Ancaman militer dan Ancaman hibrida.

\section{Pasal 19}

(1) Komponen Pendukung dikelola melalui kegiatan:

a. penataan; dan

b. pembinaan.

(2) Penataan dan pembinaan sebagaimana dimaksud pada ayat (1) diselenggarakan dalam sistem tata kelola Pertahanan Negara yang demokratis, menjunjung prinsip keadilan, menghormati hak asasi manusia, dan memperhatikan lingkungan hidup sesuai dengan ketentuan peraturan perundang-undangan. 


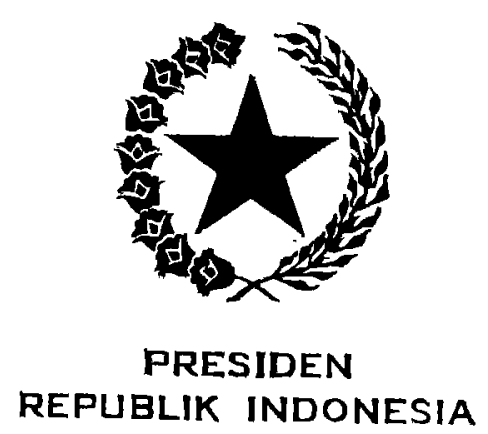

$-13-$

\section{Bagian Kedua \\ Penataan}

\section{Pasal 20}

(1) Komponen Pendukung sebagaimana dimaksud dalam Pasal 17 ayat (1) huruf a terdiri atas:

a. anggota Kepolisian Negara Republik Indonesia;

b. warga terlatih;

c. tenaga ahli; dan

d. warga lain unsur Warga Negara.

(2) Komponen Pendukung sebagaimana dimaksud dalam Pasal 17 ayat (1) huruf $b$ dan huruf $c$ terdiri atas logistik wilayah dan cadangan material strategis.

(3) Komponen Pendukung sebagaimana dimaksud dalam Pasal 17 ayat (1) huruf $d$ terdiri atas:
a. sarana dan prasarana darat;
b. sarana dan prasarana laut;
c. sarana dan prasarana udara;
d. sarana dan prasarana siber dan antariksa; dan
e. sarana dan prasarana lainnya.

\section{Pasal 21}

(1) Penataan Komponen Pendukung sebagaimana dimaksud dalam Pasal 19 ayat (1) huruf a dilaksanakan melalui tahapan:
a. penyiapan; dan
b. penetapan.

(2) Penyiapan Komponen Pendukung sebagaimana dimaksud pada ayat (1) huruf a dilaksanakan melalui tahapan kegiatan:
a. pendataan;
b. pemilahan;
c. pemilihan; dan
d. verifikasi.

(3) Berdasarkan hasil verifikasi sebagaimana dimaksud pada ayat (2) huruf d, Menteri menetapkan Komponen Pendukung. 


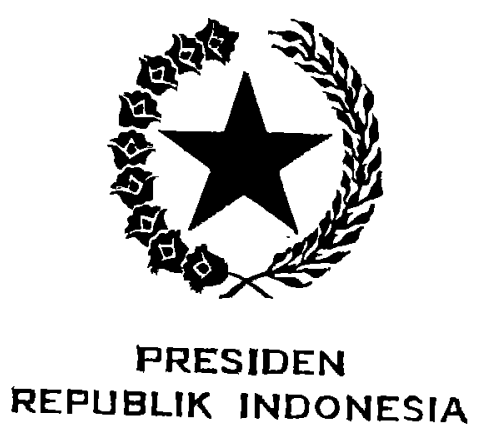

- 14 -

Pasal 22

(1) Kementerian yang menyelenggarakan urusan pemerintahan di bidang pertahanan bekerja sama dengan kementerian/lembaga dan pemerintah daerah melakukan penataan sebagaimana dimaksud dalam Pasal 21 ayat (1) terhadap Komponen Pendukung yang berada di bawah pembinaan dan/atau dikelola oleh kementerian/lembaga dan pemerintah daerah.

(2) Kementerian/lembaga dan pemerintah daerah menyerahkan data Komponen Pendukung yang diperlukan untuk pelaksanaan penataan sebagaimana dimaksud pada ayat (1).

\section{Pasal 23}

Penetapan Komponen Pendukung tidak menghilangkan:

a. hak pemilik untuk mengalihkan hak kepemilikan, mengelola, dan/atau menggunakan;

b. hak pengelola untuk mengelola dan/atau menggunakan; dan/atau

c. hak kebendaan lainnya sesuai dengan ketentuan peraturan perundang-undangan,

terhadap Sumber Daya Alam, Sumber Daya Buatan, serta Sarana dan Prasarana Nasional.

\section{Pasal 24}

Ketentuan lebih lanjut mengenai penataan Komponen Pendukung sebagaimana dimaksud dalam Pasal 20 sampai dengan Pasal 23 diatur dengan Peraturan Pemerintah.

\section{Bagian Ketiga \\ Pembinaan}

Pasal 25

(1) Pembinaan Komponen Pendukung sebagaimana dimaksud dalam Pasal 19 ayat (1) huruf b merupakan kegiatan peningkatan kualitas dan/atau kuantitas Komponen Pendukung dalam usaha Pertahanan Negara.

(2) Kebijakan ... 


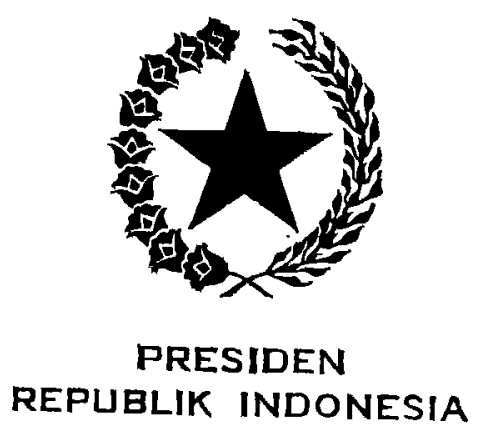

-15 -

(2) Kebijakan pembinaan Komponen Pendukung sebagaimana dimaksud pada ayat (1) disusun oleh Menteri berkoordinasi dengan menteri/pimpinan lembaga.

(3) Kementerian/lembaga dan pemerintah daerah melaksanakan kebijakan pembinaan sesuai dengan tugas dan fungsi masing-masing.

\section{Pasal 26}

(1) Pembinaan Komponen Pendukung sebagaimana dimaksud dalam Pasal 25 melalui kegiatan:

a. sosialisasi;

b. bimbingan teknis; dan/atau

c. simulasi.

(2) Kegiatan sebagaimana dimaksud pada ayat (1) dilaksanakan oleh tiap-tiap kementerian/lembaga dan pemerintah daerah yang bekerja sama dengan kementerian yang menyelenggarakan urusan pemerintahan di bidang pertahanan.

\section{Pasal 27}

Ketentuan lebih lanjut mengenai pembinaan Komponen Pendukung sebagaimana dimaksud dalam Pasal 25 dan Pasal 26 diatur dengan Peraturan Pemerintah.

\section{BAB V \\ KOMPONEN CADANGAN}

\section{Bagian Kesatu Umum}

\section{Pasal 28}

(1) Komponen Cadangan terdiri atas:

a. Warga Negara;

b. Sumber Daya Alam;

c. Sumber Daya Buatan; dan

d. Sarana dan Prasarana Nasional.

(2) Komponen ... 


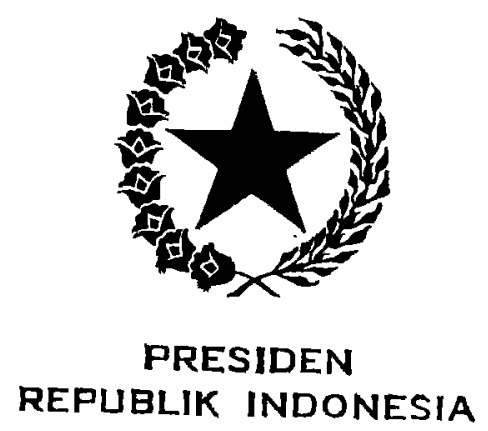

-16 -

(2) Komponen Cadangan sebagaimana dimaksud pada ayat (1) huruf a merupakan pengabdian dalam usaha pertahanan negara yang bersifat sukarela.

(3) Komponen Cadangan sebagaimana dimaksud pada ayat (1) huruf b sampai dengan huruf d merupakan pemanfaatan dalam usaha Pertahanan Negara.

\title{
Pasal 29
}

Komponen Cadangan sebagaimana dimaksud dalam Pasal 28 ayat (1) disiapkan untuk dikerahkan melalui Mobilisasi guna memperbesar dan memperkuat kekuatan dan kemampuan Komponen Utama dalam menghadapi Ancaman militer dan Ancaman hibrida.

Pasal 30

(1) Komponen Cadangan dikelola melalui kegiatan:

a. pembentukan dan penetapan;

b. pembinaan; dan

c. penggunaan dan pengembalian.

(2) Pengelolaan Komponen Cadangan sebagaimana dimaksud pada ayat (1) diselenggarakan dalam sistem tata kelola Pertahanan Negara yang demokratis, menjunjung prinsip keadilan, memperhatikan lingkungan hidup, dan menghormati hak asasi manusia sesuai dengan ketentuan peraturan perundang-undangan.

\author{
Bagian Kedua \\ Pembentukan dan Penetapan
}

\author{
Paragraf 1 \\ Pembentukan
}

\section{Pasal 31}

Pembentukan Komponen Cadangan sebagaimana dimaksud dalam Pasal 28 ayat (1) huruf a dikelompokkan menjadi:

a. Komponen Cadangan matra darat;

b. Komponen Cadangan matra laut; dan

c. Komponen Cadangan matra udara. 


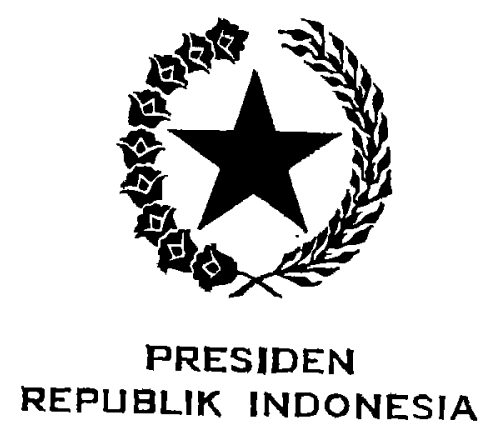

-17 -

Pasal 32

Pembentukan Komponen Cadangan sebagaimana dimaksud dalam Pasal 31 terdiri atas tahapan:
a. pendaftaran;
b. seleksi;
c. pelatihan dasar kemiliteran; dan
d. penetapan.

Pasal 33

(1) Setiap Warga Negara berhak mendaftar menjadi calon Komponen Cadangan.

(2) Setiap Warga Negara yang mendaftar menjadi calon Komponen Cadangan sebagaimana dimaksud pada ayat

(1) harus memenuhi persyaratan sebagai berikut:

a. beriman dan bertakwa kepada Tuhan Yang Maha Esa;

b. setia pada Negara Kesatuan Republik Indonesia yang berdasarkan Pancasila dan Undang-Undang Dasar Negara Republik Indonesia Tahun 1945;

c. berusia minimal 18 (delapan belas) tahun dan maksimal 35 (tiga puluh lima) tahun;

d. sehat jasmani dan rohani; dan

e. tidak memiliki catatan kriminalitas yang dikeluarkan secara tertulis oleh Kepolisian Negara Republik Indonesia.

\section{Pasal 34}

(1) Setiap calon Komponen Cadangan yang telah memenuhi persyaratan sebagaimana dimaksud dalam Pasal 33 mengikuti seleksi pembentukan.

(2) Seleksi pembentukan calon Komponen Cadangan sebagaimana dimaksud pada ayat (1) meliputi:

a. seleksi administratif; dan

b. seleksi kompetensi.

Pasal $35 \ldots$ 


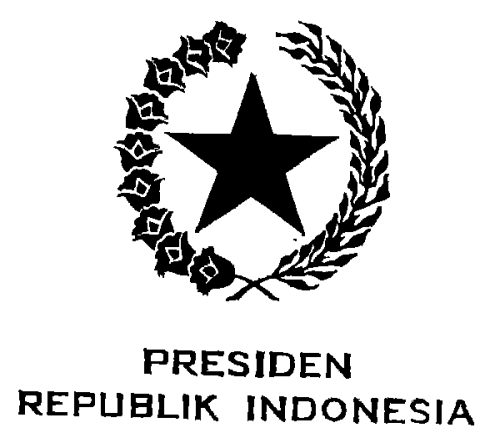

-18 -

Pasal 35

(1) Calon Komponen Cadangan yang lulus seleksi sebagaimana dimaksud dalam Pasal 34 wajib mengikuti pelatihan dasar kemiliteran selama 3 (tiga) bulan.

(2) Pelatihan dasar kemiliteran sebagaimana dimaksud pada ayat (1) menjadi tanggung jawab Menteri.

Pasal 36

Calon Komponen Cadangan selama mengikuti pelatihan dasar kemiliteran sebagaimana dimaksud dalam Pasal 35 ayat (1) berhak memperoleh:

a. uang saku;

b. perlengkapan perseorangan lapangan;

c. rawatan kesehatan; dan

d. pelindungan jaminan kecelakaan kerja dan jaminan kematian.

\section{Pasal 37}

(1) Calon Komponen Cadangan yang berasal dari unsur Aparatur Sipil Negara dan pekerja/buruh selama menjalani pelatihan dasar kemiliteran sebagai calon Komponen Cadangan tetap memperoleh hak ketenagakerjaannya dan tidak menyebabkan putusnya hubungan kerja dengan instansi atau perusahaan tempatnya bekerja.

(2) Calon Komponen Cadangan yang berstatus mahasiswa selama menjalani pelatihan dasar kemiliteran sebagai calon Komponen Cadangan tetap memperoleh hak akademisnya dan tidak menyebabkan kehilangan status sebagai peserta didik.

\section{Pasal 38}

(1) Calon Komponen Cadangan yang telah lulus mengikuti pelatihan dasar kemiliteran diangkat dan ditetapkan menjadi Komponen Cadangan.

(2) Pengangkatan ... 


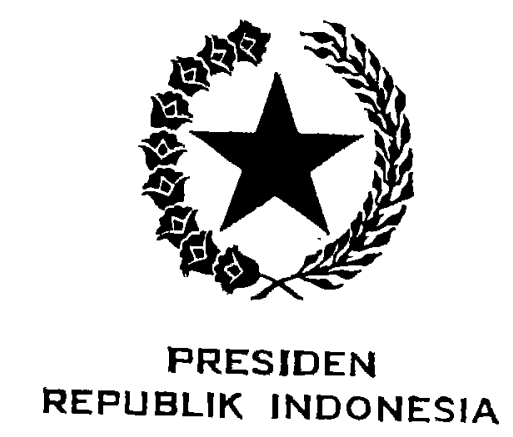

-19 -

(2) Pengangkatan dan penetapan Komponen Cadangan sebagaimana dimaksud pada ayat (1) dilaksanakan oleh Menteri.

\section{Pasal 39}

(1) Komponen Cadangan yang telah diangkat dan ditetapkan sebagaimana dimaksud dalam Pasal 38 wajib dilantik dan mengucapkan sumpah/janji Komponen Cadangan.

(2) Sumpah/janji sebagaimana dimaksud pada ayat (1) dilakukan menurut agama atau kepercayaannya kepada Tuhan Yang Maha Esa.

\section{Pasal 40}

Ketentuan lebih lanjut mengenai pembentukan Komponen Cadangan sebagaimana dimaksud dalam Pasal 31 sampai dengan Pasal 39 diatur dengan Peraturan Pemerintah.

\section{Paragraf 2}

Kewajiban dan Hak

\section{Pasal 41}

Komponen Cadangan sebagaimana dimaksud dalam Pasal 28 ayat (1) huruf a wajib:

a. setia dan taat pada Pancasila, Undang-Undang Dasar Negara Republik Indonesia Tahun 1945, dan Negara Kesatuan Republik Indonesia;

b. menjaga persatuan dan kesatuan bangsa;

c. menaati ketentuan peraturan perundang-undangan;

d. melaksanakan tugas dengan penuh pengabdian, kejujuran, kesadaran, dan tanggung jawab;

e. menunjukkan integritas dan keteladanan dalam sikap, perilaku, ucapan, dan tindakan kepada setiap orang;

f. mengikuti pelatihan penyegaran; dan

g. memenuhi panggilan Mobilisasi. 


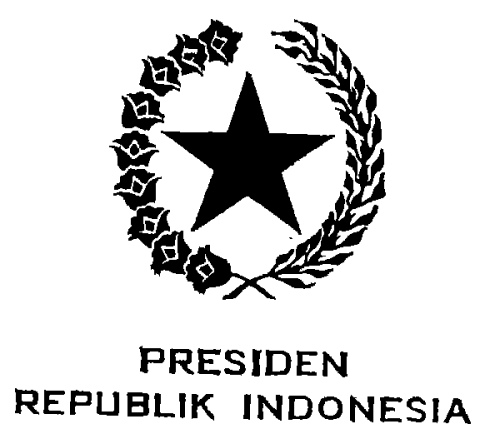

-20 -

Pasal 42

(1) Komponen Cadangan sebagaimana dimaksud dalam Pasal 28 ayat (1) huruf a berhak atas:

a. uang saku selama menjalani pelatihan;

b. tunjangan operasi pada saat Mobilisasi;

c. rawatan kesehatan;

d. pelindungan jaminan kecelakaan kerja dan jaminan kematian; dan

e. penghargaan.

(2) Ketentuan lebih lanjut mengenai besaran dan tata cara pemberian tunjangan operasi pada saat Mobilisasi sebagaimana dimaksud pada ayat (1) huruf b diatur dengan Peraturan Presiden.

\author{
Paragraf 3 \\ Masa Pengabdian
}

Pasal 43

Masa pengabdian Komponen Cadangan sebagaimana dimaksud dalam Pasal 28 ayat (1) huruf a terdiri atas:

a. masa aktif; dan

b. masa tidak aktif.

\title{
Pasal 44
}

(1) Masa aktif Komponen Cadangan sebagaimana dimaksud dalam Pasal 43 huruf a merupakan masa pengabdian Komponen Cadangan pada saat mengikuti pelatihan penyegaran dan/atau pada saat Mobilisasi.

(2) Masa tidak aktif sebagaimana dimaksud dalam Pasal 43 huruf $b$ merupakan masa pengabdian Komponen Cadangan dengan melaksanakan pekerjaan dan/atau profesi semula. 


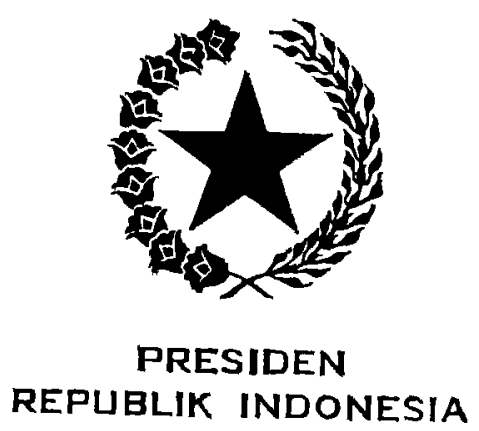

$-21-$

Pasal 45

(1) Komponen Cadangan yang berasal dari unsur Aparatur Sipil Negara dan pekerja/buruh selama menjalani masa aktif sebagaimana dimaksud dalam Pasal 44 ayat (1) tetap memperoleh hak ketenagakerjaannya dan tidak menyebabkan putusnya hubungan kerja dengan instansi atau perusahaan tempatnya bekerja.

(2) Komponen Cadangan yang berstatus mahasiswa selama menjalani masa aktif sebagaimana dimaksud dalam Pasal 44 ayat (1) tetap memperoleh hak akademisnya dan tidak menyebabkan kehilangan status sebagai peserta didik.

Pasal 46

Bagi Komponen Cadangan selama masa aktif sebagaimana dimaksud dalam Pasal 44 ayat (1) diberlakukan hukum militer.

\title{
Pasal 47
}

Komponen Cadangan melaksanakan pengabdian sebagai Komponen Cadangan sampai dengan usia paling tinggi 48 (empat puluh delapan) tahun.

\section{Pasal 48}

Ketentuan lebih lanjut mengenai masa pengabdian Komponen Cadangan sebagaimana dimaksud dalam Pasal 43 sampai dengan Pasal 47 diatur dengan Peraturan Pemerintah.

\author{
Paragraf 4 \\ Pemberhentian
}

\section{Pasal 49}

(1) Komponen Cadangan sebagaimana dimaksud dalam Pasal 28 ayat (1) huruf a diberhentikan dengan hormat jika:

a. telah menjalani masa pengabdian sampai dengan usia 48 (empat puluh delapan) tahun;

b. sakit yang menyebabkan tidak dapat melanjutkan sebagai Komponen Cadangan;

c. gugur ... 


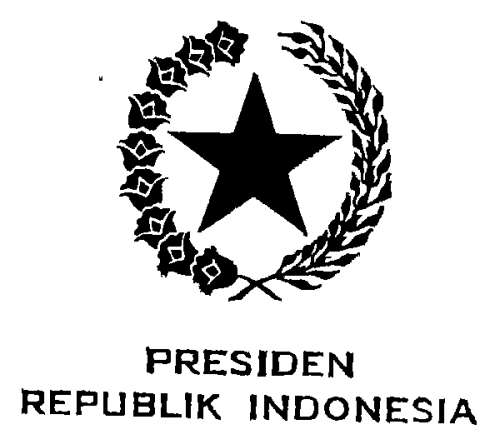

$-22-$

c. gugur, tewas, atau meninggal dunia; atau

d. tidak ada kepastian atas dirinya, setelah 6 (enam) bulan sejak dinyatakan hilang dalam tugas sebagai Komponen Cadangan.

(2) Komponen Cadangan sebagaimana dimaksud dalam Pasal 28 ayat (1) huruf a diberhentikan dengan tidak hormat jika:

a. menganut, mengembangkan, serta menyebarkan ajaran atau paham yang bertentangan dengan Pancasila;

b. menjadi anggota dalam organisasi terlarang berdasarkan putusan pengadilan yang telah memperoleh kekuatan hukum tetap dan/atau peraturan perundang-undangan;

c. melakukan tindakan yang dapat mengancam atau membahayakan keamanan dan keselamatan negara dan bangsa;

d. mempunyai tabiat dan/atau perbuatan yang nyatanyata dapat merugikan disiplin; dan/atau

e. dijatuhi pidana penjara dengan hukuman di atas 1 (satu) tahun berdasarkan putusan pengadilan yang telah memperoleh kekuatan hukum tetap.

Pasal 50

Ketentuan lebih lanjut mengenai pemberhentian Komponen Cadangan sebagaimana dimaksud dalam Pasal 49 diatur dengan Peraturan Pemerintah.

\section{Paragraf 5}

Penetapan Sumber Daya Alam, Sumber Daya Buatan, serta Sarana dan Prasarana Nasional

\section{Pasal 51}

Sumber Daya Alam, Sumber Daya Buatan, serta Sarana dan Prasarana Nasional sebagaimana dimaksud dalam Pasal 28 ayat (1) huruf $b$, huruf $c$, dan huruf d ditetapkan menjadi Komponen Cadangan setelah melalui tahapan:
a. verifikasi; dan
b. klasifikasi. 


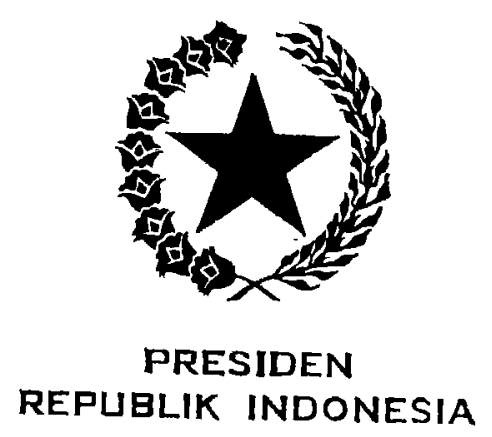

$-23-$

Pasal 52

(1) Verifikasi sebagaimana dimaksud dalam Pasal 51 huruf a dilaksanakan melalui kegiatan pendataan terhadap Sumber Daya Alam, Sumber Daya Buatan, serta Sarana dan Prasarana Nasional yang memenuhi syarat sebagai Komponen Cadangan.

(2) Sumber Daya Alam, Sumber Daya Buatan, serta Sarana dan Prasarana Nasional yang diverifikasi sebagaimana dimaksud pada ayat (1) berasal dari Sumber Daya Alam, Sumber Daya Buatan, serta Sarana dan Prasarana Nasional yang ditetapkan sebagai Komponen Pendukung.

Pasal 53

Sumber Daya Alam, Sumber Daya Buatan, serta Sarana dan Prasarana Nasional yang telah diverifikasi sebagaimana dimaksud dalam Pasal 52 diklasifikasikan melalui kegiatan pemilahan dan pengelompokan sesuai dengan kematraan Komponen Cadangan sebagaimana dimaksud dalam Pasal 31.

\section{Pasal 54}

(1) Setelah tahapan klasifikasi sebagaimana dimaksud dalam Pasal 53, Sumber Daya Alam, Sumber Daya Buatan, serta Sarana dan Prasarana Nasional ditetapkan menjadi Komponen Cadangan.

(2) Penetapan Sumber Daya Alam, Sumber Daya Buatan, serta Sarana dan Prasarana Nasional sebagaimana dimaksud pada ayat (1) dilaksanakan oleh Menteri.

(3) Dalam menetapkan Sumber Daya Alam, Sumber Daya Buatan, serta Sarana dan Prasarana Nasional sebagaimana dimaksud pada ayat (1), Menteri terlebih dahulu berkoordinasi dengan menteri/pimpinan lembaga terkait.

(4) Penetapan Komponen Cadangan sebagaimana dimaksud pada ayat (2) diberitahukan kepada pemilik atau pengelola Sumber Daya Alam, Sumber Daya Buatan, serta Sarana dan Prasarana Nasional. 


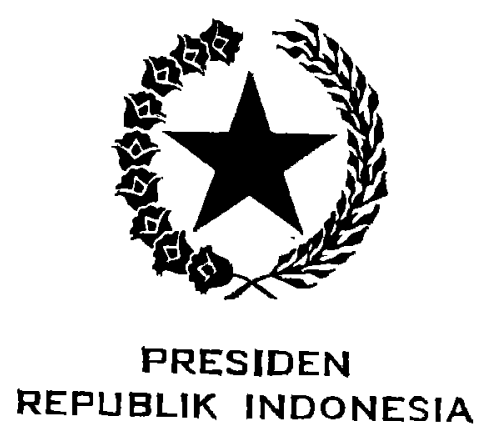

-24 -

Pasal 55

Penetapan Komponen Cadangan sebagaimana dimaksud dalam Pasal 54 tidak menghilangkan:

a. hak pemilik untuk mengalihkan hak kepemilikan, mengelola, dan/atau menggunakan; dan/atau

b. hak pengelola untuk mengelola dan/atau menggunakan, terhadap Sumber Daya Alam, Sumber Daya Buatan, serta Sarana dan Prasarana Nasional.

\title{
Pasal 56
}

Ketentuan lebih lanjut mengenai penetapan Sumber Daya Alam, Sumber Daya Buatan, serta Sarana dan Prasarana Nasional sebagaimana dimaksud dalam Pasal 51 sampai dengan Pasal 55 diatur dengan Peraturan Pemerintah.

\author{
Bagian Ketiga \\ Pembinaan \\ Paragraf 1 \\ Warga Negara
}

Pasal 57

(1) Pembinaan Komponen Cadangan sebagaimana dimaksud dalam Pasal 28 ayat (1) huruf a merupakan kegiatan yang bertujuan untuk meningkatkan kualitas, nilai guna, dan daya guna untuk kepentingan Pertahanan Negara.

(2) Pembinaan Komponen Cadangan sebagaimana dimaksud pada ayat (1) dilaksanakan dengan mengacu pada kebijakan umum Pertahanan Negara.

(3) Pembinaan Komponen Cadangan sebagaimana dimaksud pada ayat (1) menjadi tanggung jawab Menteri.

Pasal $58 \ldots$ 


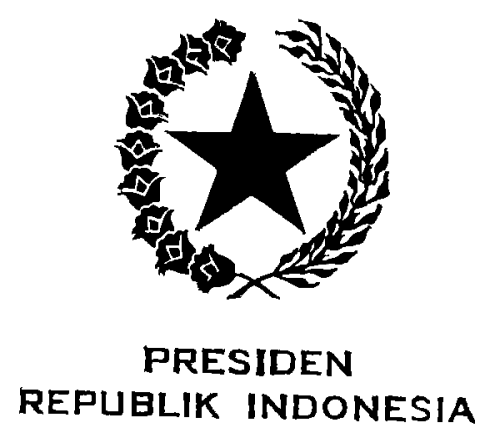

-25 -

Pasal 58

(1) Pembinaan Komponen Cadangan sebagaimana dimaksud dalam Pasal 57 dilakukan selama masa pengabdian sesuai dengan matra sebagaimana dimaksud dalam Pasal 31.

(2) Pembinaan Komponen Cadangan sebagaimana dimaksud pada ayat (1) meliputi kegiatan pembinaan administratif dan pembinaan kemampuan.

\section{Paragraf 2}

Sumber Daya Alam, Sumber Daya Buatan, serta Sarana dan Prasarana Nasional

\section{Pasal 59}

(1) Pembinaan Komponen Cadangan sebagaimana dimaksud dalam Pasal 28 ayat (1) huruf b, huruf c, dan huruf d dilakukan melalui pemeliharaan dan perawatan.

(2) Pemeliharaan dan perawatan sebagaimana dimaksud pada ayat (1) dilaksanakan oleh pemilik atau pengelola Sumber Daya Alam, Sumber Daya Buatan, serta Sarana dan Prasarana Nasional di bawah supervisi kementerian/ lembaga terkait sesuai dengan tugas dan fungsi.

Pasal 60

Ketentuan lebih lanjut mengenai pembinaan Komponen Cadangan sebagaimana dimaksud dalam Pasal 57 sampai dengan Pasal 59 diatur dengan Peraturan Pemerintah.

\section{Bagian Keempat \\ Penggunaan dan Pengembalian}

Pasal 61

(1) Komponen Cadangan sebagaimana dimaksud dalam Pasal 28 digunakan untuk memperbesar dan memperkuat Komponen Utama setelah pernyataan Mobilisasi oleh Presiden.

(2) Penggunaan ... 


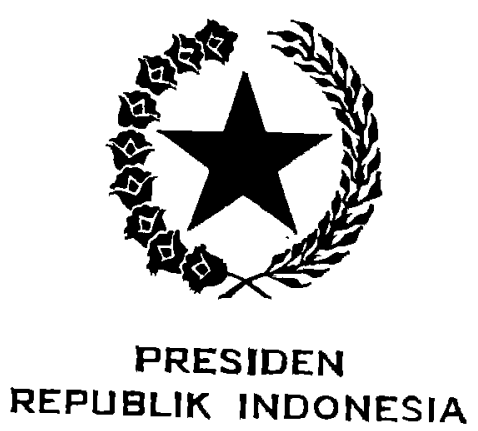

$-26-$

(2) Penggunaan Komponen Cadangan sebagaimana dimaksud pada ayat (1) berada di bawah komando dan kendali Panglima Tentara Nasional Indonesia.

\title{
Pasal 62
}

(1) Komponen Cadangan dikembalikan setelah pernyataan Demobilisasi oleh Presiden.

(2) Pengembalian Komponen Cadangan berada di bawah komando dan kendali Panglima Tentara Nasional Indonesia.

\section{BAB VI \\ MOBILISASI DAN DEMOBILISASI}

\author{
Bagian Kesatu \\ Mobilisasi
}

\section{Pasal 63}

(1) Dalam hal seluruh atau sebagian wilayah Negara Kesatuan Republik Indonesia dalam keadaan darurat militer atau keadaan perang, Presiden dapat menyatakan Mobilisasi.

(2) Dalam menyatakan Mobilisasi sebagaimana dimaksud pada ayat (1), Presiden harus mendapatkan persetujuan Dewan Perwakilan Rakyat.

\section{Pasal 64}

(1) Mobilisasi dikenakan terhadap Komponen Cadangan.

(2) Komponen Pendukung yang dikenai Mobilisasi harus ditingkatkan statusnya menjadi Komponen Cadangan.

\section{Pasal 65}

(1) Komponen Pendukung yang tidak ditingkatkan statusnya menjadi Komponen Cadangan wajib memberikan dukungan pada saat Mobilisasi yang dikoordinasikan oleh kementerian/lembaga sesuai dengan tugas dan fungsi.

(2) Komponen ... 


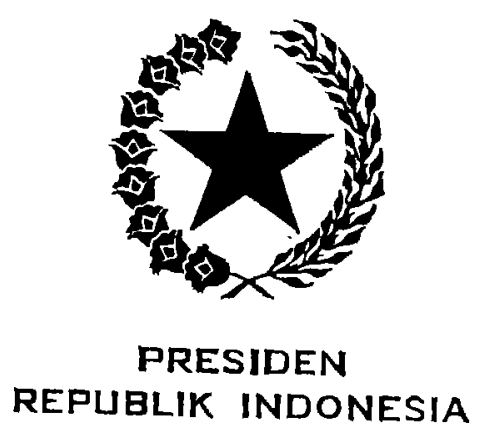

-27 -

(2) Komponen Pendukung sebagaimana dimaksud pada ayat (1) bersifat nonkombatan.

\section{Pasal 66}

(1) Komponen Cadangan yang berasal dari unsur Warga Negara wajib memenuhi panggilan untuk Mobilisasi.

(2) Setiap pemilik dan/atau pengelola Sumber Daya Alam, Sumber Daya Buatan, serta Sarana dan Prasarana Nasional yang ditetapkan statusnya sebagai Komponen Cadangan wajib menyerahkan pemanfaatannya untuk kepentingan Mobilisasi.

Pasal 67

(1) Komponen Cadangan sebagaimana dimaksud dalam Pasal 66 ayat (1) yang gugur, tewas, dinyatakan hilang, dan/atau cacat selama melaksanakan tugas Mobilisasi diperlakukan dan diberikan hak sesuai dengan ketentuan peraturan perundang-undangan.

(2) Sumber Daya Alam, Sumber Daya Buatan, serta Sarana dan Prasarana Nasional milik swasta atau perseorangan yang digunakan pada saat Mobilisasi, diperlakukan sebagai milik negara, dan diberi rawatan kedinasan sesuai dengan sistem pembinaan materiel dilaksanakan sesuai dengan ketentuan peraturan perundang-undangan.

(3) Segala bentuk pajak yang dikenakan atas Sumber Daya Alam, Sumber Daya Buatan, serta Sarana dan Prasarana Nasional milik swasta atau perseorangan yang digunakan selama Mobilisasi dibebankan kepada negara dan dilaksanakan sesuai dengan ketentuan peraturan perundang-undangan.

(4) Sumber... 


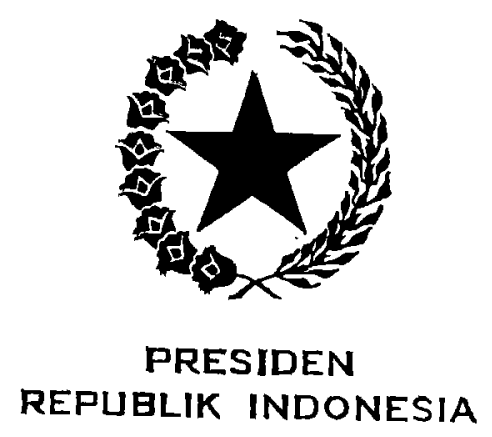

-28 -

(4) Sumber Daya Alam, Sumber Daya Buatan, serta Sarana dan Prasarana Nasional milik swasta atau perseorangan yang digunakan pada saat Mobilisasi tidak menyebabkan putusnya hubungan kepemilikan dengan pemiliknya dan/atau pengelolanya.

Pasal 68

Ketentuan lebih lanjut mengenai Mobilisasi sebagaimana dimaksud dalam Pasal 63 sampai dengan Pasal 67 diatur dengan Peraturan Pemerintah.

Bagian Kedua

Demobilisasi

Pasal 69

(1) Dalam hal keadaan darurat militer atau keadaan perang sebagaimana dimaksud dalam Pasal 63 sudah dapat diatasi, Presiden menyatakan Demobilisasi dengan persetujuan Dewan Perwakilan Rakyat.

(2) Demobilisasi sebagaimana dimaksud pada ayat (1) diberlakukan bagi Komponen Cadangan.

\section{Pasal 70}

Demobilisasi sebagaimana dimaksud dalam Pasal 69 diselenggarakan secara bertahap guna memulihkan fungsi dan tugas umum pemerintahan dan kehidupan sosial ekonomi masyarakat.

\section{Pasal 71}

(1) Komponen Cadangan sebagaimana dimaksud dalam Pasal 66 ayat (1) yang telah selesai di-Mobilisasi dikembalikan ke fungsi dan status semula melalui Demobilisasi.

(2) Pemerintah . . 


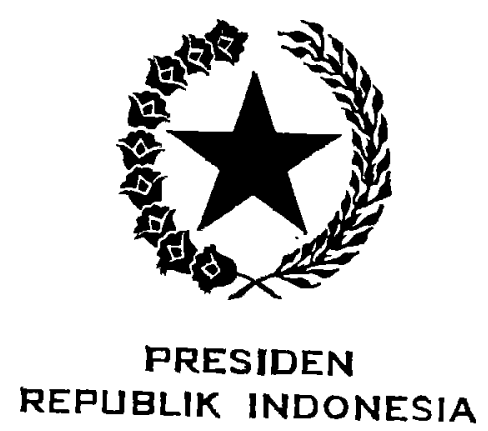

-29 -

(2) Pemerintah wajib mengembalikan Komponen Cadangan sebagaimana dimaksud pada ayat (1) dengan didahului rehabilitasi.

\section{Pasal 72}

(1) Sumber Daya Alam, Sumber Daya Buatan, serta Sarana dan Prasarana Nasional milik Pemerintah dan pemerintah daerah, milik swasta, dan milik perseorangan yang telah selesai di-Mobilisasi wajib dikembalikan ke fungsi dan status semula melalui Demobilisasi.

(2) Pemerintah wajib mengembalikan Sumber Daya Alam, Sumber Daya Buatan, serta Sarana dan Prasarana Nasional milik Pemerintah dan pemerintah daerah, milik swasta, milik perseorangan sebagaimana dimaksud pada ayat (1) dengan disertai kompensasi sesuai dengan kemampuan keuangan Negara.

(3) Sumber Daya Alam, Sumber Daya Buatan, serta Sarana dan Prasarana Nasional sebagaimana dimaksud pada ayat (2) dikembalikan kepada pemilik dan/atau pengelola setelah Demobilisasi paling lama 3 (tiga) tahun.

\section{Pasal 73}

Komponen Cadangan yang telah di-Mobilisasi dan pengelola dan/atau pemilik yang menyerahkan pemanfaatan Sumber Daya Alam, Sumber Daya Buatan, serta Sarana dan Prasarana Nasional untuk Mobilisasi dianugerahi tanda kehormatan dan/atau gelar kehormatan oleh negara sesuai dengan ketentuan peraturan perundang-undangan.

\section{Pasal 74}

Ketentuan lebih lanjut mengenai Demobilisasi sebagaimana dimaksud dalam Pasal 69 sampai dengan Pasal 73 diatur dengan Peraturan Pemerintah.

BAB VII ... 


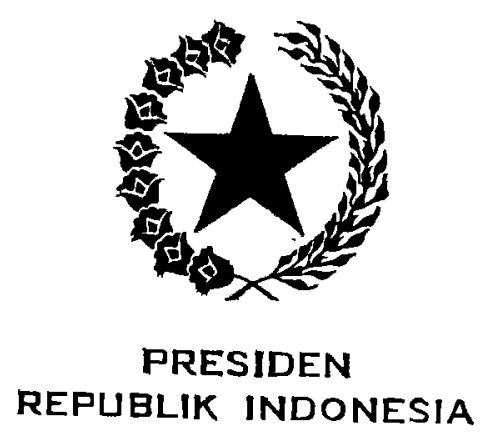

$-30-$

\section{BAB VII \\ PENDANAAN}

Pasal 75

Pendanaan yang diperlukan untuk pengelolaan Sumber Daya Nasional untuk Pertahanan Negara sebagaimana dimaksud dalam Pasal 3 bersumber dari:

a. Anggaran Pendapatan dan Belanja Negara;

b. anggaran pendapatan dan belanja daerah; dan/atau

c. sumber pendanaan lain yang sah dan tidak mengikat yang diatur dengan peraturan perundang-undangan.

\section{BAB VIII \\ PENGAWASAN}

Pasal 76

(1) Pengawasan usaha Bela Negara, penataan Komponen Pendukung, dan pembentukan Komponen Cadangan dilaksanakan oleh komisi di Dewan Perwakilan Rakyat yang mempunyai ruang lingkup tugas di bidang pertahanan.

(2) Pengawasan oleh komisi di Dewan Perwakilan Rakyat sebagaimana dimaksud pada ayat (1) dilaksanakan sesuai dengan ketentuan peraturan perundang-undangan.

BAB IX

KETENTUAN PIDANA

Pasal 77

(1) Setiap Komponen Cadangan yang dengan sengaja membuat dirinya tidak memenuhi panggilan Mobilisasi atau melakukan tipu muslihat yang menyebabkan dirinya terhindar dari Mobilisasi sebagaimana dimaksud dalam Pasal 66 ayat (1) dipidana dengan pidana penjara paling lama 4 (empat) tahun.

(2) Setiap ... 


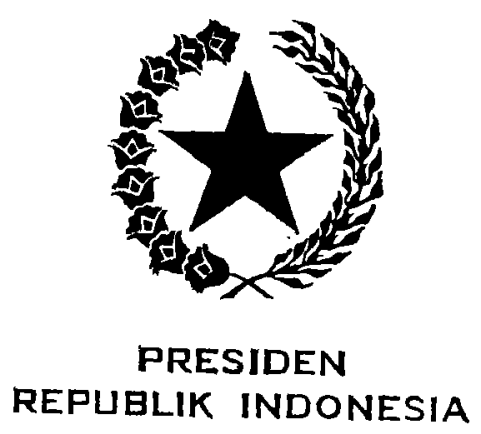

$-31-$

(2) Setiap orang yang dengan sengaja atau melakukan tipu muslihat membuat Komponen Cadangan tidak memenuhi panggilan Mobilisasi sebagaimana dimaksud dalam Pasal 66 ayat (1) dipidana dengan pidana penjara paling lama 2 (dua) tahun.

\section{Pasal 78}

(1) Setiap pemberi kerja dan/atau pengusaha atau lembaga pendidikan yang dengan sengaja menyebabkan putusnya hubungan kerja atau hubungan pendidikan bagi calon Komponen Cadangan selama melaksanakan pelatihan dasar kemiliteran sebagaimana dimaksud dalam Pasal 37 dipidana dengan pidana penjara paling lama 2 (dua) tahun.

(2) Setiap pemberi kerja dan/atau pengusaha atau lembaga pendidikan yang dengan sengaja menyebabkan putusnya hubungan kerja atau hubungan pendidikan bagi Komponen Cadangan selama menjalani masa aktif sebagaimana dimaksud dalam Pasal 45 dipidana dengan pidana penjara paling lama 4 (empat) tahun.

\section{Pasal 79}

(1) Setiap orang yang dengan sengaja atau tanpa alasan yang sah tidak menyerahkan pemanfaatan sebagian atau. seluruh Sumber Daya Alam, Sumber Daya Buatan, dan/atau Sarana dan Prasarana Nasional miliknya yang telah ditetapkan menjadi Komponen Cadangan untuk digunakan dalam Mobilisasi sebagaimana dimaksud dalam Pasal 66 ayat (2) dipidana dengan pidana penjara paling lama 4 (empat) tahun.

(2) Setiap orang yang melakukan tipu muslihat sehingga menyebabkan dirinya atau orang lain tidak menyerahkan sebagian atau seluruh Sumber Daya Alam, Sumber Daya Buatan, dan/atau Sarana dan Prasarana Nasional miliknya yang telah ditetapkan menjadi Komponen Cadangan untuk digunakan dalam Mobilisasi sebagaimana dimaksud dalam Pasal 66 ayat (2) dipidana dengan pidana penjara paling lama 4 (empat) tahun.

Pasal $80 \ldots$ 


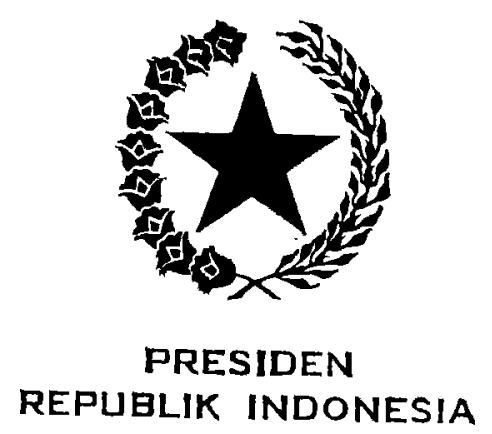

$-32-$

Pasal 80

Setiap pejabat yang dengan sengaja menyalahgunakan kekuasaannya dengan tidak menyerahkan kembali Sumber Daya Alam, Sumber Daya Buatan, dan/atau Sarana dan Prasarana Nasional Komponen Cadangan yang telah digunakan dalam Mobilisasi kepada pemilik semula sebagaimana dimaksud dalam Pasal 72 ayat (2) dipidana dengan pidana penjara paling lama 5 (lima) tahun 4 (empat) bulan.

\section{Pasal 81}

Setiap orang yang dengan sengaja memberikan atau menjanjikan sesuatu kepada orang lain, mempengaruhi dengan kekerasan atau dengan ancaman kekerasan, atau menganjurkan orang lain untuk tidak menyerahkan sebagian atau seluruh pemanfaatan Sumber Daya Alam, Sumber Daya Buatan, dan/atau Sarana dan Prasarana Nasional Komponen Cadangan yang diperlukan untuk kepentingan Mobilisasi sebagaimana dimaksud dalam Pasal 66 ayat (2) dipidana dengan pidana penjara paling lama 5 (lima) tahun 4 (empat) bulan.

\section{Pasal 82}

Setiap orang yang karena kealpaannya tidak menyerahkan kembali Sumber Daya Alam, Sumber Daya Buatan, dan/atau Sarana dan Prasarana Nasional yang telah digunakan dalam Mobilisasi kepada pengelola dan/atau pemilik semula dan/atau tidak melaksanakan pengembalian Sumber Daya Alam, Sumber Daya Buatan, dan/atau Sarana dan Prasarana Nasional ke fungsi dan status semula sebagaimana dimaksud dalam Pasal 72 ayat (1) dipidana dengan pidana penjara paling lama 2 (dua) tahun.

\section{Pasal 83}

Setiap pejabat yang karena kealpaannya tidak menyerahkan kembali Sumber Daya Alam, Sumber Daya Buatan, dan/atau Sarana dan Prasarana Nasional Komponen Cadangan yang telah digunakan dalam Mobilisasi kepada pengelola dan/atau pemilik semula sebagaimana dimaksud dalam Pasal 72 ayat (2) dipidana dengan pidana penjara paling lama 2 (dua) tahun 8 (delapan) bulan. 


\section{(1) \\ PRESIDEN \\ REPUBLIK INDONESIA \\ -33 - \\ BAB X \\ KETENTUAN PENUTUP}

Pasal 84

Pada saat Undang-Undang ini berlaku semua peraturan pelaksanaan Undang-Undang Nomor 27 Tahun 1997 tentang Mobilisasi dan Demobilisasi (Lembaran Negara Republik Indonesia Tahun 1997 Nomor 75, Tambahan Lembaran Negara Republik Indonesia Nomor 3704) dan Undang-Undang Nomor 56 Tahun 1999 tentang Rakyat Terlatih (Lembaran Negara Republik Indonesia Tahun 1999 Nomor 184, Tambahan Lembaran Negara Republik Indonesia Nomor 3905) dinyatakan tetap berlaku sepanjang tidak bertentangan atau diganti dengan yang baru berdasarkan Undang-Undang ini.

Pasal 85

Pada saat Undang-Undang ini mulai berlaku:

a. Undang-Undang Nomor 27 Tahun 1997 tentang Mobilisasi dan Demobilisasi (Lembaran Negara Republik Indonesia Tahun 1997 Nomor 75, Tambahan Lembaran Negara Republik Indonesia Nomor 3704); dan

b. Undang-Undang Nomor 56 Tahun 1999 tentang Rakyat Terlatih (Lembaran Negara Republik Indonesia Tahun 1999 Nomor 184, Tambahan Lembaran Negara Republik Indonesia Nomor 3905), dicabut dan dinyatakan tidak berlaku.

\section{Pasal 86}

Peraturan pelaksanaan dari Undang-Undang ini ditetapkan paling lama 2 (dua) tahun terhitung sejak Undang-Undang ini diundangkan.

\section{Pasal 87}

Undang-Undang ini mulai berlaku pada tanggal diundangkan.

Agar . . . 


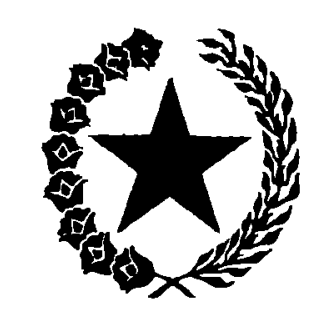

PRESIDEN

REPUBLIK INDONESIA

-34 -

\begin{abstract}
Agar setiap orang mengetahuinya, memerintahkan pengundangan Undang-Undang ini dengan penempatannya dalam Lembaran Negara Republik Indonesia.
\end{abstract}

Disahkan di Jakarta

pada tanggal 24 Oktober 2019

PRESIDEN REPUBLIK INDONESIA,

ttd.

JOKO WIDODO

Diundangkan di Jakarta

pada tanggal 24 Oktober 2019

MENTERI HUKUM DAN HAK ASASI MANUSIA

REPUBLIK INDONESIA,

ttd.

YASONNA H. LAOLY

LEMBARAN NEGARA REPUBLIK INDONESIA TAHUN 2019 NOMOR 211

Salinan sesuai dengan aslinya

KEMENTERIAN SEKRETARIAT NEGARA

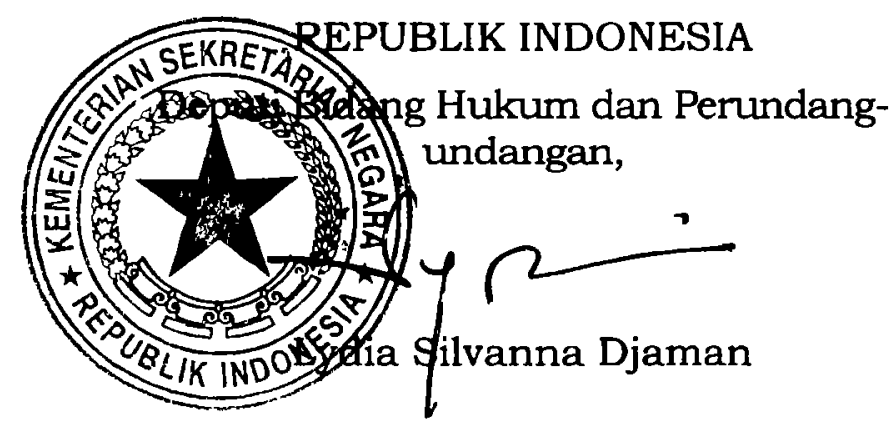




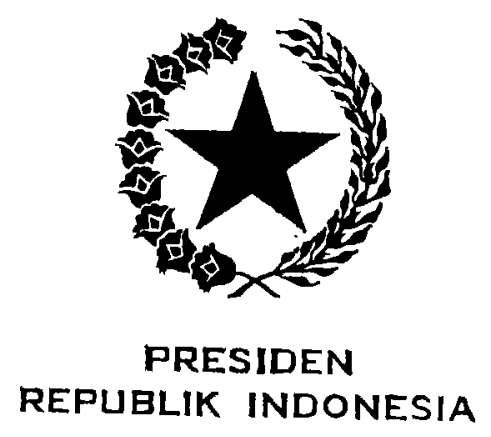

PENJELASAN

ATAS

UNDANG-UNDANG REPUBLIK INDONESIA

NOMOR TAHUN

TENTANG

PENGELOLAAN SUMBER DAYA NASIONAL

UNTUK PERTAHANAN NEGARA

\section{UMUM}

Pertahanan Negara bagi suatu bangsa yang berdaulat merupakan suatu cara untuk menjaga, melindungi, dan mempertahankan keutuhan, persatuan dan kesatuan, serta kedaulatan bangsa terhadap segala bentuk Ancaman. Bangsa Indonesia memiliki cara sendiri untuk membangun sistem Pertahanan Negaranya, yaitu sistem pertahanan yang bersifat semesta dengan melibatkan seluruh Warga Negara, wilayah, dan Sumber Daya Nasional lainnya, yang dipersiapkan secara dini oleh Pemerintah dan diselenggarakan secara total, terpadu, terarah, dan berkelanjutan untuk menegakkan kedaulatan negara, keutuhan wilayah, dan keselamatan segenap bangsa dari segala Ancaman.

Konsep Pertahanan Negara yang bersifat semesta tersebut lahir dari sejarah panjang perjuangan rakyat Indonesia yang diawali pada masa penjajahan, masa kemerdekaan, masa mengisi kemerdekaan sampai sekarang. Kesemestaan yang dibangun telah terbukti mampu merebut dan mempertahankan kemerdekaan dari kaum kolonialis pada masa revolusi perang kemerdekaan.

Hakikat Pertahanan Negara yang bersifat semesta tersebut, penyelenggaraannya didasarkan pada kesadaran atas hak dan kewajiban Warga Negara serta keyakinan pada kekuatan sendiri, yang disusun berdasarkan prinsip demokrasi, hak asasi manusia, kesejahteraan umum, lingkungan hidup, ketentuan hukum nasional, hukum internasional, dan kebiasaan internasional, serta prinsip hidup berdampingan secara damai dengan memperhatikan kondisi geografis Indonesia sebagai negara kepulauan dan negara maritim.

Melalui ... 


\section{( \\ PRESIDEN \\ REPUBLIK INDONESIA}

$-2-$

Melalui prinsip dasar tersebut, tujuan penyelenggaraan Pertahanan Negara adalah untuk menjaga dan melindungi kedaulatan negara, keutuhan wilayah Negara Kesatuan Republik Indonesia, serta keselamatan segenap bangsa. Dalam mencapai tujuan tersebut, fungsi Pertahanan Negara diselenggarakan dengan memanfaatkan seluruh potensi Sumber Daya Nasional serta Sarana dan Prasarana Nasional sebagai bagian penting dari komponen Pertahanan Negara sekaligus digunakan bagi kesejahteraan rakyat.

Pengelolaan Sumber Daya Nasional untuk Pertahanan Negara bertujuan untuk mentransformasikan Sumber Daya Nasional menjadi kekuatan Pertahanan Negara yang siap digunakan untuk kepentingan Pertahanan Negara melalui usaha Bela Negara, penataan Komponen Pendukung, dan pembentukan Komponen Cadangan.

Bela Negara merupakan hak dan kewajiban bagi setiap Warga Negara yang diselenggarakan melalui usaha Pertahanan Negara untuk menegakkan kedaulatan negara, menjaga keutuhan wilayah Negara Kesatuan Republik Indonesia, dan keselamatan segenap bangsa. Bela Negara dilaksanakan atas dasar kesadaran Warga Negara serta keyakinan pada kekuatan sendiri yang ditumbuhkembangkan melalui usaha Bela Negara. Usaha Bela Negara diselenggarakan melalui pendidikan kewarganegaraan, pelatihan dasar kemiliteran secara wajib, pengabdian sebagai prajurit Tentara Nasional Indonesia secara sukarela atau secara wajib, dan pengabdian sesuai dengan profesi. Usaha Bela Negara bertujuan untuk memelihara jiwa nasionalisme Warga Negara dalam upaya pemenuhan hak dan kewajibannya terhadap Bela Negara yang diwujudkan dengan Pembinaan Kesadaran Bela Negara demi tercapainya tujuan dan kepentingan nasional.

Komponen Pendukung merupakan salah satu wadah dan bentuk keikutsertaan Warga Negara dan pemanfaatan Sumber Daya Nasional lainnya dalam usaha Pertahanan Negara yang secara langsung atau tidak langsung dapat digunakan untuk meningkatkan kekuatan dan kemampuan Komponen Utama dan Komponen Cadangan dalam menghadapi Ancaman militer. Komponen Pendukung terdiri atas Warga Negara, Sumber Daya Alam, Sumber Daya Buatan, serta Sarana dan Prasarana Nasional. Pengelolaan Komponen Pendukung meliputi kegiatan penataan dan pembinaan yang dilaksanakan oleh kementerian/lembaga berdasarkan kebijakan umum Pertahanan Negara. Pengelolaan Komponen Pendukung dilaksanakan dalam sistem tata kelola Pertahanan Negara yang demokratis, berkeadilan, dan menghormati hak asasi manusia serta menaati peraturan perundang-undangan. 


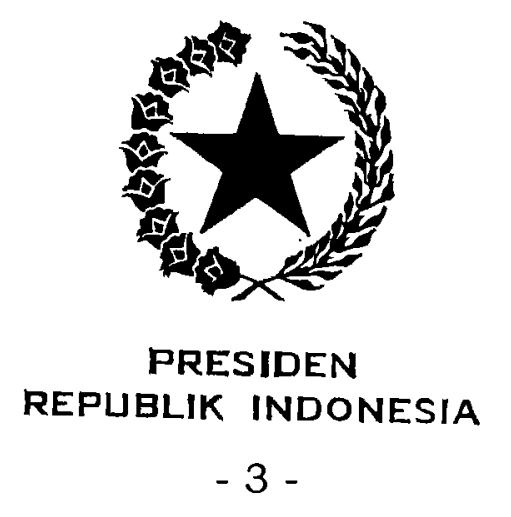

Komponen Cadangan merupakan salah satu wadah dan bentuk keikutsertaan Warga Negara serta Sarana dan Prasarana Nasional dalam usaha Pertahanan Negara. Pengelolaan Komponen Cadangan dilaksanakan oleh Menteri berdasarkan kebijakan umum Pertahanan Negara dengan menerapkan sistem tata kelola Pertahanan Negara yang demokratis, berkeadilan, dan menghormati hak asasi manusia serta menaati peraturan perundang-undangan. Pengelolaan Komponen Cadangan meliputi kegiatan pembentukan dan penetapan, pembinaan, penggunaan dan pengembalian. Komponen Cadangan dibentuk dengan tujuan untuk memperbesar dan memperkuat kekuatan dan kemampuan Tentara Nasional Indonesia sebagai Komponen Utama setelah pernyataan Mobilisasi oleh Presiden.

Mobilisasi merupakan tindakan pengerahan dan penggunaan secara serentak Sumber Daya Nasional yang telah dibina dan dipersiapkan sebagai komponen kekuatan Pertahanan Negara untuk dipergunakan secara tepat, terpadu, dan terarah bagi penanggulangan Ancaman militer atau keadaan perang yang membahayakan wilayah dan kedaulatan Negara Kesatuan Republik Indonesia. Penyelenggaraan Mobilisasi digunakan untuk menanggulangi setiap Ancaman yang membahayakan keselamatan negara dan keutuhan wilayah serta kedaulatan Negara Kesatuan Republik Indonesia. Mobilisasi dapat dikenakan kepada seluruh komponen Pertahanan Negara sesuai dengan kebutuhan strategi Pertahanan Negara.

Dalam hal Ancaman militer yang membahayakan wilayah dan kedaulatan Negara Kesatuan Republik Indonesia sudah dapat diatasi, Presiden dapat menyatakan Demobilisasi. Demobilisasi merupakan tindakan penghentian pengerahan dan penghentian penggunaan Sumber Daya Nasional yang berlaku untuk seluruh wilayah negara yang diselenggarakan secara bertahap guna memulihkan fungsi dan tugas setiap unsur seperti sebelum berlakunya Mobilisasi. Tujuan penyelenggaraan Demobilisasi adalah pemulihan kembali fungsi dan tugas setiap unsur kekuatan bangsa dan seluruh Sumber Daya Nasional serta Sarana dan Prasarana Nasional yang telah dikerahkan melalui Mobilisasi. Demobilisasi diselenggarakan secara bertahap dengan mengutamakan pemulihan penyelenggaraan tugas umum pemerintah dan kehidupan sosial ekonomi masyarakat. Mobilisasi dan Demobilisasi dinyatakan oleh Presiden dengan persetujuan Dewan Perwakilan Rakyat.

II. PASAL ... 


\section{$\theta$ \\ PRESIDEN \\ REPUBLIK INDONESIA}

$-4-$

\section{PASAL DEMI PASAL}

Pasal 1

Cukup jelas.

Pasal 2

Huruf a

Yang dimaksud dengan "asas tujuan" adalah pengelolaan Sumber Daya Nasional harus dilaksanakan secara terukur dan mengarah pada pencapaian tujuan untuk mentransformasikan Sumber Daya Nasional menjadi kekuatan Pertahanan Negara.

\section{Huruf b}

Yang dimaksud dengan "asas kesemestaan" adalah keterlibatan seluruh Sumber Daya Nasional yang dimiliki meliputi Sumber Daya Manusia, Sumber Daya Alam, Sumber Daya Buatan, serta Sarana dan Prasarana Nasional dalam usaha Pertahanan Negara.

Huruf c

Yang dimaksud dengan "asas kejuangan" adalah penyelenggara negara dan seluruh rakyat Indonesia harus memiliki mental, tekad, jiwa dan semangat pengabdian, kerelaan berkorban, serta memiliki disiplin yang tinggi dengan lebih mengutamakan kepentingan bangsa dan negara di atas kepentingan pribadi dan/atau golongan yang dilaksanakan dengan penuh kejujuran, kebenaran, dan keadilan.

Huruf d

Yang dimaksud dengan "asas kebersamaan dan gotong royong" adalah setiap Warga Negara pada setiap lapisan masyarakat secara bersama-sama harus memperoleh dan menggunakan kesempatan yang sama di dalam peran sertanya untuk Bela Negara.

Huruf e

Yang dimaksud dengan "asas manfaat" adalah segala usaha dalam menyelenggarakan Pertahanan Negara yang memberikan manfaat sebesar-besarnya untuk pembangunan Pertahanan Negara dan kesejahteraan rakyat.

Huruf $f$... 


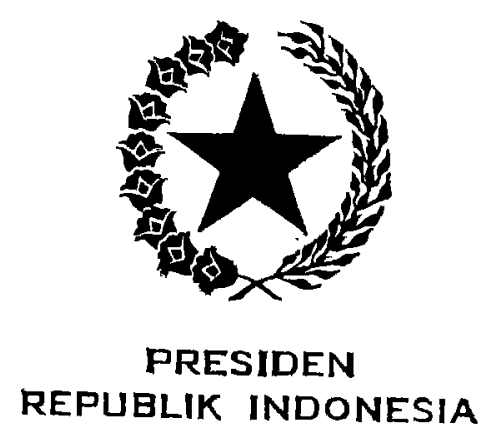

-5 -

Huruf $f$

Yang dimaksud dengan "asas legalitas" adalah pengelolaan Sumber Daya Nasional serta Sarana dan Prasarana Nasional untuk Pertahanan Negara yang dilaksanakan berdasarkan ketentuan peraturan perundang-undangan.

Huruf g

Yang dimaksud dengan "asas selektivitas" adalah pengelolaan Sumber Daya Nasional serta Sarana dan Prasarana Nasional yang dilakukan secara selektif dengan mendahulukan yang paling siap dan paling tepat untuk dikembangkan menjadi bagian kekuatan operasional Pertahanan Negara.

Huruf h

Yang dimaksud dengan "asas efektivitas" adalah pengelolaan Sumber Daya Nasional serta Sarana dan Prasarana Nasional yang dilakukan secara tepat sasaran dan berhasil guna.

Huruf i

Yang dimaksud dengan "asas efisiensi" adalah pengelolaan Sumber Daya Nasional serta Sarana dan Prasarana Nasional yang dilaksanakan secara tepat guna untuk mendapatkan manfaat sebesar-besarnya dan hasil yang terbaik bagi kepentingan Pertahanan Negara.

Huruf j

Yang dimaksud dengan "asas proporsionalitas" adalah pengelolaan Sumber Daya Nasional serta Sarana dan Prasarana Nasional yang dilaksanakan secara proporsional sesuai dengan eskalasi dan spektrum Ancaman yang dihadapi.

\section{Pasal 3}

Yang dimaksud dengan "mentransformasikan" adalah mengubah dan/atau meningkatkan nilai guna dan daya guna terhadap Sumber Daya Nasional serta Sarana dan Prasarana Nasional dari yang semula digunakan untuk fungsi sipil diubah dan/atau ditingkatkan sehingga dapat digunakan sebagai bagian penting dari Pertahanan Negara.

Pasal 4

Ayat (1)

Cukup jelas. 


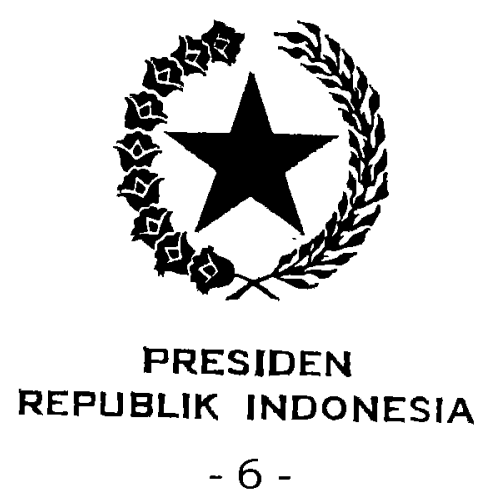

Ayat (2)

Huruf a

Cukup jelas.

Huruf b

Cukup jelas.

Huruf c

Yang dimaksud dengan "Ancaman hibrida" adalah Ancaman yang bersifat campuran dan merupakan keterpaduan antara Ancaman militer dan Ancaman nonmiliter.

Ayat (3)

Cukup jelas.

Pasal 5

Ayat (1)

Cukup jelas.

Ayat (2)

Yang dimaksud dengan "peraturan perundang-undangan" dalam ketentuan ini adalah undang-undang yang mengatur mengenai Tentara Nasional Indonesia.

Pasal 6

Ayat (1)

Usaha Bela Negara diwujudkan dalam setiap aktivitas Warga Negara, baik fisik maupun nonfisik, sesuai dengan kapasitas dan kompetensinya, meliputi ideologi, politik, ekonomi, sosial dan budaya, serta pertahanan keamanan dalam masa damai dan masa perang.

Ayat (2)

Huruf a

Dalam pendidikan kewarganegaraan sudah tercakup pemahaman tentang kesadaran Bela Negara.

Huruf $b$

Cukup jelas.

Huruf c

Cukup jelas.

Huruf d ... 


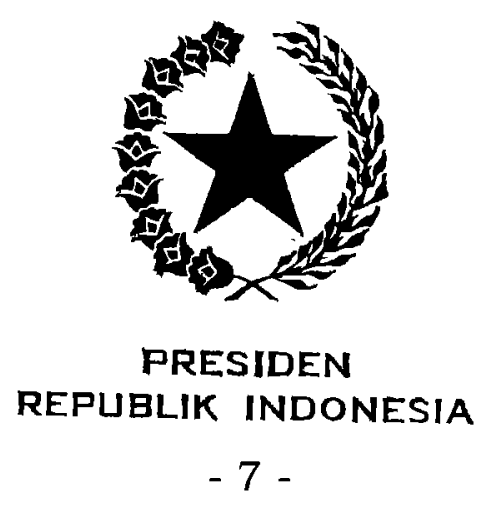

Huruf d

Yang dimaksud dengan "pengabdian sesuai dengan profesi" adalah pengabdian Warga Negara yang mempunyai profesi tertentu untuk kepentingan Pertahanan Negara, termasuk dalam menanggulangi dan/atau memperkecil akibat yang ditimbulkan oleh perang, bencana alam, atau bencana lainnya.

Ayat (3)

Cukup jelas.

Ayat (4)

Cukup jelas.

Ayat (5)

Cukup jelas.

Pasal 7

Cukup jelas.

Pasal 8

Cukup jelas.

Pasal 9

Huruf a

Cukup jelas.

Huruf b

Cukup jelas.

Huruf c

Cukup jelas.

Huruf d

Cukup jelas.

Huruf e

Cukup jelas.

Huruf $f$

Cukup jelas.

Huruf g

Cukup jelas.

Huruf h . . . 


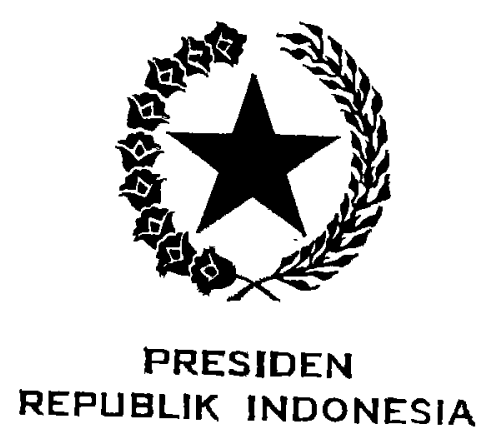

-8 -

Huruf $h$

Yang dimaksud dengan "kelompok masyarakat lainnya" antara lain adalah kader organisasi pemuda dan kader organisasi mahasiswa.

Pasal 10

Huruf a

Cukup jelas.

Huruf b

Cukup jelas.

Huruf c

Cukup jelas.

Huruf d

Cukup jelas.

Huruf e

Cukup jelas.

Huruf $\mathrm{f}$

Cukup jelas.

Huruf g

Yang dimaksud dengan "badan lain" antara lain adalah yayasan dan koperasi.

Pasal 11

Ayat (1)

Cukup jelas.

Ayat (2)

Yang dimaksud dengan "pihak lainnya" antara lain adalah pihak swasta, organisasi kemasyarakatan, korporasi, dan perkumpulan.

Ayat (3)

Cukup jelas.

Pasal 12

Ayat (1)

Yang dimaksud dengan "kebijakan Pembinaan Kesadaran Bela Negara" antara lain adalah rencana induk dan rencana aksi.

Ayat (2) ... 


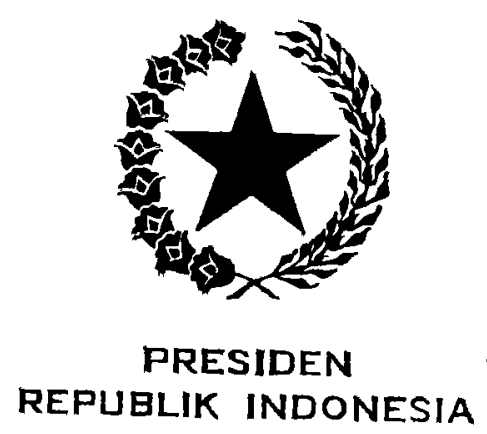

-9 -

Ayat (2)

Cukup jelas.

Ayat (3)

Cukup jelas.

\section{Pasal 13}

Cukup jelas.

\section{Pasal 14}

Yang dimaksud dengan "peraturan perundang-undangan" dalam ketentuan ini adalah undang-undang yang mengatur mengenai Tentara Nasional Indonesia.

\section{Pasal 15}

Cukup jelas.

Pasal 16

Ayat (1)

Yang dimaksud dengan "wajib" adalah tindakan yang harus dilakukan oleh Pemerintah sebagai bentuk tanggung jawab untuk melakukan pembinaan Warga Negara sesuai dengan profesinya yang dipersiapkan secara dini untuk kepentingan Pertahanan Negara.

Ayat (2)

Cukup jelas.

Ayat (3)

Cukup jelas.

\section{Pasal 17}

Ayat (1)

Cukup jelas.

Ayat (2)

Yang dimaksud "sukarela" dalam ketentuan pasal ini adalah sikap dan perilaku warga negara yang dijiwai oleh kecintaannya kepada Negara Kesatuan Republik Indonesia yang berdasarkan Pancasila dan Undang-Undang Dasar Negara Republik Indonesia Tahun 1945. 


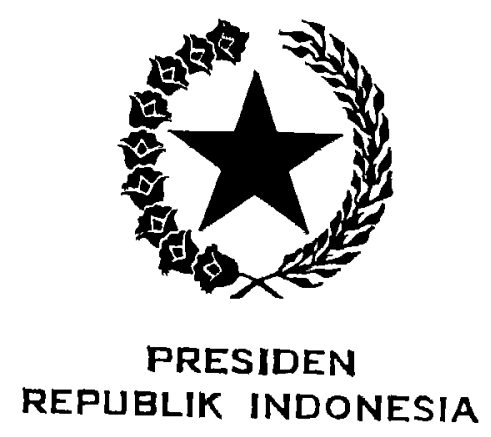

-10 -

Pasal 18

Yang dimaksud dengan penggunaan "secara langsung" adalah penggunaan Sumber Daya Nasional yang karena keberadaan dan fungsinya dapat langsung digunakan untuk meningkatkan kekuatan dan kemampuan Komponen Utama.

Yang dimaksud dengan penggunaan "secara tidak langsung" adalah penggunaan Sumber Daya Nasional yang karena keberadaan dan fungsinya dapat digunakan untuk meningkatkan kekuatan dan kemampuan Komponen Utama melalui proses menjadi Komponen Cadangan.

Pasal 19

Cukup jelas.

Pasal 20

Ayat (1)

Huruf a

Cukup jelas.

Huruf b

Yang dimaksud dengan "warga terlatih" adalah Warga Negara yang terlatih dan terorganisasi dalam lembaga pemerintah atau lembaga nonpemerintah sesuai dengan kebutuhan dan tujuan organisasi yang siap menjadi komponen Pertahanan Negara. Yang termasuk sebagai warga terlatih antara lain adalah:

a. purnawirawan Tentara Nasional Indonesia dan Kepolisian Negara Republik Indonesia;

b. anggota resimen mahasiswa;

c. anggota satuan polisi pamong praja;

d. anggota polisi khusus;

e. anggota satuan pengamanan;

f. anggota pelindungan masyarakat; dan

g. anggota organisasi kemasyarakatan lain yang dapat dipersamakan dengan warga terlatih.

Huruf c ... 


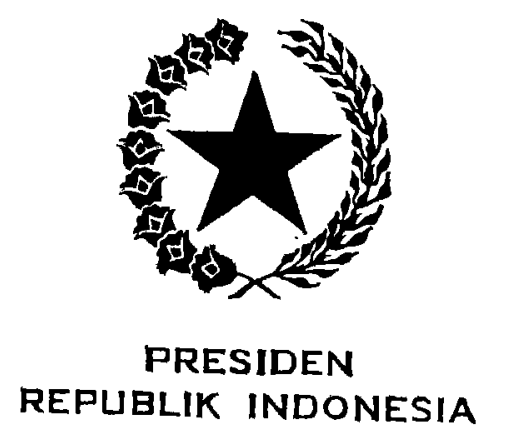

$-11-$

Huruf c

Yang dimaksud dengan "tenaga ahli" adalah Warga Negara yang mempunyai keahlian sesuai dengan bidang ilmu pengetahuan yang ditekuni. Pengelompokan tenaga ahli ditentukan sesuai dengan kecabangan Komponen Utama dan Komponen Cadangan untuk kepentingan Pertahanan Negara.

Huruf d

Yang dimaksud dengan "warga lain unsur Warga Negara" adalah Warga Negara yang tidak termasuk dalam Komponen Utama, Komponen Cadangan, warga terlatih, dan tenaga ahli tetapi memenuhi syarat secara fisik dan psikis untuk menjadi Komponen Pendukung. Warga lain unsur Warga Negara antara lain adalah:

a. anggota veteran Republik Indonesia;

b. Aparatur Sipil Negara; dan

c. individu.

Ayat (2)

Yang dimaksud dengan "logistik wilayah" adalah logistik yang disiapkan bertumpu pada kekayaan sumber daya wilayah yang meliputi Sumber Daya Alam dan Sumber Daya Buatan antara lain berupa bekal makanan, bekal perlengkapan perseorangan, bekal bahan bakar minyak dan pelumas, bekal bahan bangunan dan konstruksi, bekal amunisi dan bahan peledak, bekal kesehatan, bekal suku cadang, dan bekal lain yang dibutuhkan untuk kepentingan Pertahanan Negara.

Yang dimaksud dengan "cadangan material strategis" adalah bahan dan/atau hasil pertambangan serta alat peralatan hasil industri untuk pertahanan yang dipersiapkan sebagai persediaan guna memenuhi kebutuhan Pertahanan Negara antara lain berupa: mineral logam, batubara, hasil pengilangan minyak bumi, hasil pengilangan gas alam, hasil industri petrokimia, alat peralatan hasil industri, dan material strategis lainnya.

Ayat (3)

Cukup jelas. 


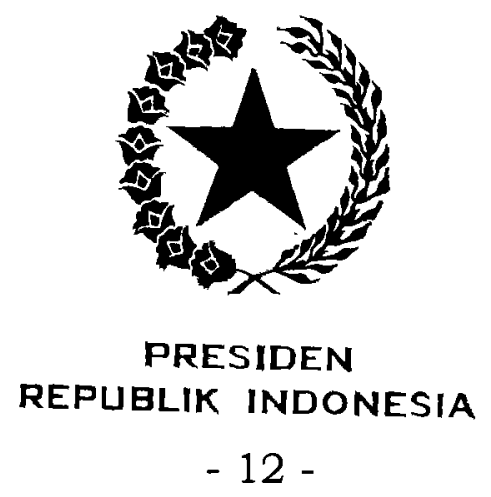

Pasal 21

Cukup jelas.

Pasal 22

Cukup jelas.

Pasal 23

Cukup jelas.

Pasal 24

Cukup jelas.

Pasal 25

Cukup jelas.

Pasal 26

Cukup jelas.

Pasal 27

Cukup jelas.

Pasal 28

Cukup jelas.

Pasal 29

Cukup jelas.

Pasal 30

Ayat (1)

Huruf a

Pembentukan dalam ketentuan ini diperuntukkan bagi Komponen Cadangan yang berasal dari unsur Warga Negara.

Penetapan dalam ketentuan ini diperuntukkan bagi Komponen Cadangan yang berasal dari unsur Sumber Daya Alam, Sumber Daya Buatan, serta Sarana dan Prasarana Nasional.

Huruf b

Cukup jelas. 


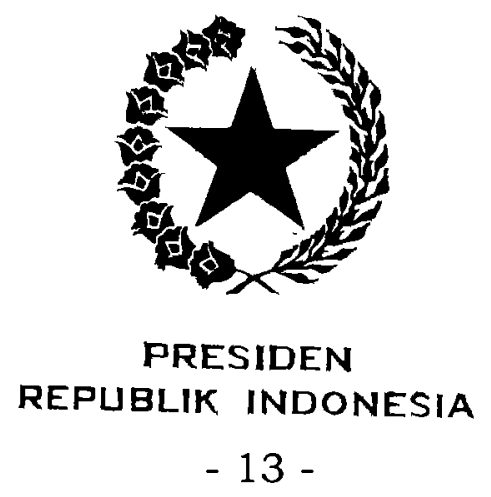

Huruf c

Cukup jelas.

Ayat (2)

Cukup jelas.

Pasal 31

Cukup jelas.

Pasal 32

Cukup jelas.

Pasal 33

Cukup jelas.

Pasal 34

Cukup jelas.

Pasal 35

Cukup jelas.

Pasal 36

Cukup jelas.

Pasal 37

Ayat (1)

Yang dimaksud dengan "pekerja/buruh" adalah setiap orang yang bekerja dengan menerima upah atau imbalan dalam bentuk lain.

Ayat (2)

Cukup jelas.

\section{Pasal 38}

Cukup jelas.

Pasal 39

Cukup jelas.

Pasal 40

Cukup jelas. 


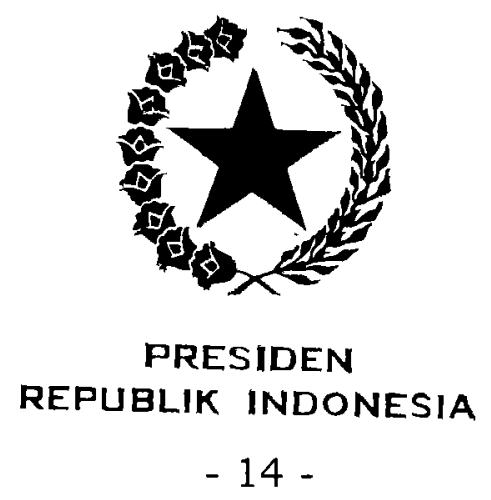

Pasal 41

Cukup jelas.

Pasal 42

Cukup jelas.

Pasal 43

Cukup jelas.

Pasal 44

Cukup jelas.

Pasal 45

Cukup jelas.

Pasal 46

Yang dimaksud dengan "diberlakukan hukum militer" adalah Komponen Cadangan selama masa aktif tunduk pada ketentuan yang berlaku bagi militer.

Yang dimaksud dengan "hukum militer" adalah semua perundangundangan nasional yang subjek hukumnya anggota militer atau orang yang dipersamakan sebagai militer berdasarkan peraturan perundang-undangan.

Pasal 47

Cukup jelas.

Pasal 48

Cukup jelas.

Pasal 49

Cukup jelas.

Pasal 50

Cukup jelas.

Pasal 51

Cukup jelas. 


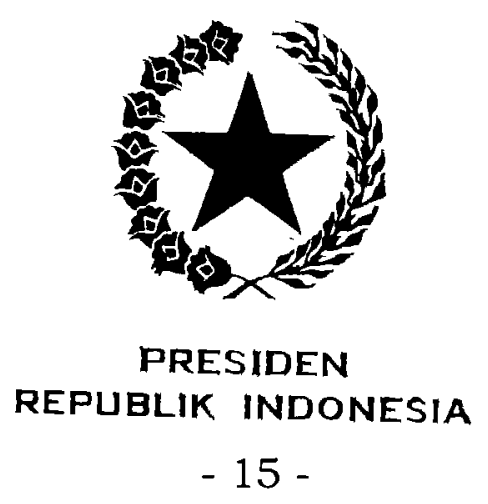

Pasal 52

Cukup jelas.

Pasal 53

Cukup jelas.

Pasal 54

Ayat (1)

Cukup jelas.

Ayat (2)

Cukup jelas.

Ayat (3)

Dalam menetapkan Sumber Daya Alam, Sumber Daya Buatan, serta Sarana dan Prasarana Nasional sebagai Komponen Cadangan, Menteri terlebih dahulu berkoordinasi dengan menteri/pimpinan lembaga terkait agar perubahan status Sumber Daya Alam, Sumber Daya Buatan, serta Sarana dan Prasarana Nasional tersebut diketahui oleh kementerian/ lembaga yang menjadi pembina Sumber Daya Alam, Sumber Daya Buatan, serta Sarana dan Prasarana Nasional.

Ayat (4)

Cukup jelas.

Pasal 55

Cukup jelas.

Pasal 56

Cukup jelas.

Pasal 57

Cukup jelas.

Pasal 58

Cukup jelas.

Pasal 59

Cukup jelas. 


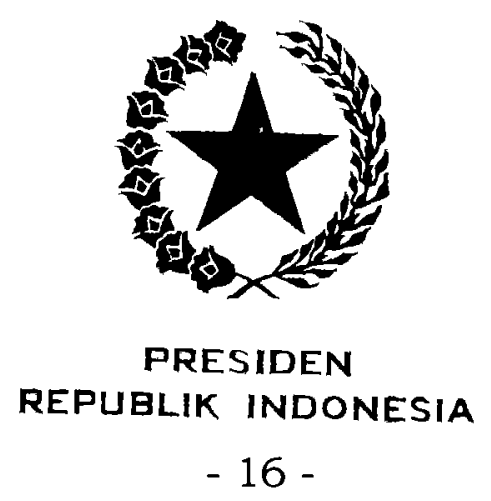

Pasal 60

Cukup jelas.

Pasal 61

Cukup jelas.

Pasal 62

Cukup jelas.

Pasal 63

Cukup jelas.

Pasal 64

Cukup jelas.

Pasal 65

Cukup jelas.

Pasal 66

Cukup jelas.

Pasal 67

Ayat (1)

Yang dimaksud dengan "peraturan perundang-undangan" dalam ketentuan ini adalah peraturan perundang-undangan yang mengatur mengenai Tentara Nasional Indonesia.

Ayat (2)

Cukup jelas.

Ayat (3)

Yang dimaksud dengan "peraturan perundang-undangan" antara lain adalah undang-undang yang mengatur mengenai ketentuan umum perpajakan.

Ayat (4)

Cukup jelas.

\section{Pasal 68}

Cukup jelas.

Pasal $69 \ldots$ 


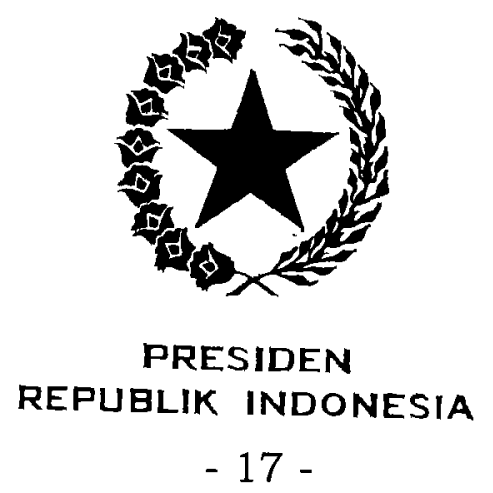

Pasal 69

Ayat (1)

Cukup jelas.

Ayat (2)

Komponen Cadangan dalam ketentuan ini merupakan

Komponen Cadangan yang telah diangkat dan ditetapkan sebelum Mobilisasi dan Komponen Pendukung yang telah ditingkatkan statusnya menjadi Komponen Cadangan pada saat Mobilisasi.

Pasal 70

Cukup jelas.

Pasal 71

Ayat (1)

Yang dimaksud dengan "dikembalikan ke fungsi dan status semula" adalah Komponen Cadangan yang telah digunakan dan sebelum dikembalikan harus difungsikan kembali seperti sebelum Mobilisasi.

Ayat (2)

Yang dimaksud dengan "didahului rehabilitasi" adalah bentuk pemulihan kondisi dari Warga Negara sebagai Komponen Cadangan setelah digunakan melalui Mobilisasi. Pemberian rehabilitasi ditujukan agar Warga Negara setelah digunakan dalam Mobilisasi dikembalikan ke masyarakat dan diharapkan mampu untuk beradaptasi dengan lingkungan masyarakat sebagaimana layaknya.

Rehabilitasi dilakukan antara lain dalam bentuk rehabilitasi sosial dan/atau rehabilitasi medik.

Rehabilitasi sosial adalah suatu proses kegiatan pemulihan secara terpadu, baik fisik, mental, maupun sosial agar Warga Negara sebagai Komponen Cadangan dapat kembali beradaptasi dan melaksanakan fungsi sosial dalam kehidupan bermasyarakat.

Rehabilitasi Medik adalah upaya untuk mengembalikan status kesehatan serta mengembalikan fungsi tubuh akibat penyakit dan/atau akibat cacat atau menghilangkan cacat.

Pasal $72 \ldots$ 


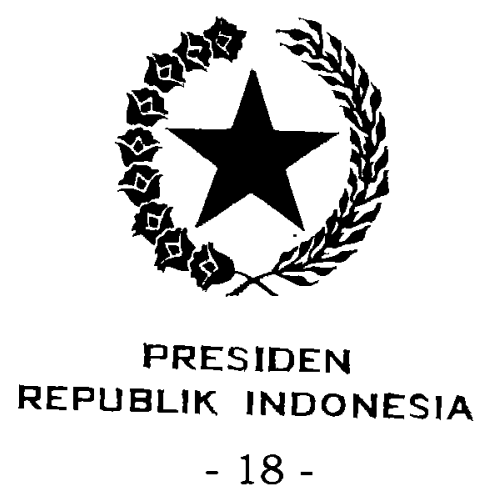

\section{Pasal 72}

Ayat (1)

Yang dimaksud dengan "Sumber Daya Alam, Sumber Daya Buatan, serta Sarana dan Prasarana Nasional milik Pemerintah dan pemerintah daerah" adalah Sumber Daya Alam, Sumber Daya Buatan, serta Sarana dan Prasarana Nasional milik Pemerintah yang pengelolaan sepenuhnya menjadi kewenangan Pemerintah dan pemerintah daerah, baik itu berupa badan usaha milik negara dan/atau badan usaha milik daerah.

Ayat (2)

Yang dimaksud dengan "kompensasi" dalam ketentuan ini adalah ganti rugi yang diberikan oleh negara dapat berupa uang atau bukan uang.

Pemberian kompensasi dilakukan sesuai dengan ketentuan peraturan perundang-undangan.

Ayat (3)

Cukup jelas.

\section{Pasal 73}

Cukup jelas.

Pasal 74

Cukup jelas.

\section{Pasal 75}

Cukup jelas.

Pasal 76

Cukup jelas.

\section{Pasal 77}

Cukup jelas.

Pasal 78

Cukup jelas.

Pasal 79

Cukup jelas. 


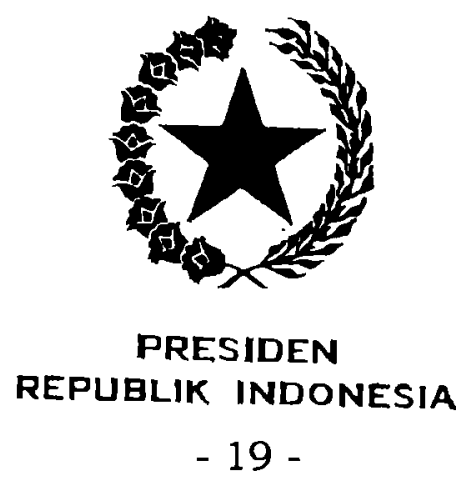

Pasal 80

Cukup jelas.

Pasal 81

Cukup jelas.

Pasal 82

Cukup jelas.

Pasal 83

Cukup jelas.

Pasal 84

Cukup jelas.

Pasal 85

Cukup jelas.

Pasal 86

Cukup jelas.

Pasal 87

Cukup jelas.

TAMBAHAN LEMBARAN NEGARA REPUBLIK INDONESIA NOMOR 6413 